This item was submitted to Loughborough's Research Repository by the author.

Items in Figshare are protected by copyright, with all rights reserved, unless otherwise indicated.

\title{
Bank performance and the financial crisis: evidence from Kazakhstan
}

PLEASE CITE THE PUBLISHED VERSION

http://dx.doi.org/10.1080/09603107.2013.868584

PUBLISHER

(C) Taylor \& Francis

VERSION

AM (Accepted Manuscript)

LICENCE

CC BY-NC-ND 4.0

REPOSITORY RECORD

Glass, Anthony J., Karligash Kenjegalieva, and Thomas G. Weyman-Jones. 2019. "Bank Performance and the Financial Crisis: Evidence from Kazakhstan”. figshare. https://hdl.handle.net/2134/13939. 
This item was submitted to Loughborough's Institutional Repository (https://dspace.lboro.ac.uk/) by the author and is made available under the following Creative Commons Licence conditions.

\section{creative
commons}

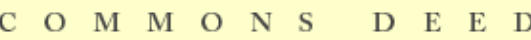

Attribution-NonCommercial-NoDerivs 2.5

You are free:

- to copy, distribute, display, and perform the work

Under the following conditions:

Attribution. You must attribute the work in the manner specified b the author or licensor.

Noncommercial. You may not use this work for commercial purposes.

No Derivative Works. You may not alter, transform, or build upon this work.

- For any reuse or distribution, you must make clear to others the license terms of this work.

- Any of these conditions can be waived if you get permission from the copyright holder.

Your fair use and other rights are in no way affected by the above.

This is a human-readable summary of the Leqal Code (the full license).

\section{Disclaimer 만}

For the full text of this licence, please go to: http://creativecommons.org/licenses/by-nc-nd/2.5/ 


\title{
Bank Performance and the Financial Crisis: EVIDENCE FROM KAZAKHSTAN
}

\author{
Anthony J. Glass*, Karligash Kenjegalieva*†and Thomas Weyman-Jones*
}

\begin{abstract}
During the first phase of the financial crisis in 2008/09, after Iceland and Belgium, Kazakhstan experienced the most significant bank failures as a share of bank system assets. Using rich monthly data for virtually the entire Kazakh banking industry for the period March 2007-December 2010, Stochastic Frontier Analysis (SFA) is used to fit several functions (cost, revenue, standard profit, alternative profit and input distance). Among other things, we estimate the effects of two measures of the quality and risk of the loan portfolio on the industry best practice frontiers and bank inefficiencies. We find that an increase in the volume of bad loans as a ratio of total lending has a desirable effect on the cost, input-distance and alternative profit frontiers, all of which is consistent with the 'skimping' hypothesis.
\end{abstract}

Keywords: Banking performance; Bad loans; Stochastic Frontier Analysis

JEL Classification: C51; G21; G28; P34

${ }^{*}$ School of Business and Economics, Loughborough University, Leics, UK, LE11 3TU. Email addresses: A.J.Glass@lboro.ac.uk; K.A.Kenjegalieva@lboro.ac.uk; T.G.Weyman-Jones@lboro.ac.uk.

$\dagger$ Corresponding author. Address: School of Business and Economics, Loughborough University, Leics, UK, LE11 3TU. E-mail: K.A.Kenjegalieva@lboro.ac.uk. Tel.: +44(0)1509222708; fax: +44(0)1509222701. 
'There is a better model for Ireland than Iceland ... People should be looking at Kazakhstan, which didn't bail out any creditors and let the three biggest banks fail, yet avoided a recession by letting the currency plunge and using monetary stimulus...'

The Telegraph, 8 December 2010

\section{Introduction}

The recent global financial crisis has resulted in banking crises in a range of countries. As a share of total bank system assets, the biggest bank failures during the first phase of the financial crisis in 2008/09 were in Iceland (circa 90\%) followed by Belgium (53\%), Kazakhstan (28\%) and the UK (26\%) (Laeven and Valencia, 2010). During the financial crisis, the capital of the entire Kazakh banking sector was negative because of the large negative equity of two of the country's largest banks (BTA and Alliance). Because both banks were considered too-bigto-fail the government decided to nationalize them but having done so it turned out they were too-big-to-save and the government declared that it would not guarantee the foreign liabilities of any banks. Consequently, BTA and Alliance defaulted on their foreign liabilities.

The recent turmoil in the banking sector has focused attention on banking performance and, in particular, on the quality of bank assets and credit risk. Many studies of banking performance have attempted to estimate the effect of loan quality and risk on banking efficiency and productivity. The earlier studies analyze the effect of loan quality and banking risk on the efficiency of U.S. banks (e.g. Mester, 1996, and Berger and Mester, 1997). In general, these studies observe a negative relationship between problem loans and banking efficiency. This relationship, however, may be a phenomenon that relates to periods of bad luck, bad management, 'skimping' and moral hazard (Berger and DeYoung, 1997). More recent studies investigate the risk-performance nexus for European banks. This literature is wide ranging and includes cross country studies (e.g. Iannotta et al., 2007) and studies of banking efficiency in Greece (Pasiouras, 2008), Japan (Altunbas et al., 2000), emerging economies (Isik and Hassan, 2002), East Asian countries (Sun and Chang, 2011, Kwan, 2003, and Chiu and Chen, 2009) and transition countries (Havrylchyk, 2006, Kenjegalieva et al., 2009, Kraft and Tirtiroglu, 1998 and Brissimis et al., 2008).

Using rich monthly data for virtually the entire Kazakh banking industry for a study period (March 2007-December 2010) which includes the financial crisis, we draw on the financial intermediation approach to apply Stochastic Frontier Analysis (SFA) to fit several functions (cost, revenue, standard profit, alternative profit and input distance). The fitted functions are used to investigate the effect of the quality and risk of the loan portfolio on the industry best practice frontiers, and the economic and technical inefficiencies of individual banks, whilst controlling for other bank specific characteristics. Since the study period includes the financial crisis we pay particular attention to the performance of BTA and Alliance.

This paper contributes to the banking literature in four ways. Firstly, whereas most banking 
studies use the overall level of problem loans and/or provisions for loan losses as proxies for banking risk, we use data which classifies loans into seven categories according to their quality and riskiness. Specifically, two classifications are used. The first is based on the volume of loans and the second is based on the level of provision for loan losses. Both classifications split the bank loan portfolio into standard, bad and doubtful loans with a further five sub-categories of the latter. We observe some interesting differences between the effects of the two classifications on the industry best practice frontiers and banking inefficiencies. These differences are likely to be because the loan loss provisions classification will reflect not only issuance behavior but also managerial discretion on loan reserves to manipulate profit. For this reason we posit that the volume of bad loans as a share of total assets, rather than the ratio of reserves on bad loans to total assets, should be used to monitor the level of non-performing loans in the Kazakh banking sector, which is still a big issue for the industry despite some improvement in this area since the height of the financial crisis.

Secondly, our approach is similar to Hughes and Mester (1993) and Berger and Mester (1997) but whereas they estimate cost and profit functions to analyze the effect of risk on the industry best practice frontiers and bank inefficiencies, we fit a further three functions. In addition, here the modeling of the best practice frontiers takes into account inter-bank heteroscedasticity in inefficiency effects and unobservable heterogeneity in the banks' technologies. Thirdly, to the best of the authors' knowledge this is the first study to analyze banking performance in Kazakhstan. It is the largest landlocked country, has substantial oil reserves and in the early 2000s it was one of the fastest growing economies in the world with growth comparable to the East Asian tigers. ${ }^{1}$

Fourthly, the determinants of the industry best practice frontiers and banking inefficiencies are used to inform a discussion of the characteristics of Kazakh bank behavior during the recent financial crisis. We find that an increase in the volume of bad loans as a ratio of total lending has a desirable effect on the cost, input-distance and alternative profit frontiers, all of which is consistent with the 'skimping' hypothesis.

The remainder of this paper is organized as follows. Section 2 provides an overview of banking sector developments in Kazakhstan and in Section 3 we set out the empirical methodology. Section 4 describes the data set and in section 5 the empirical results are presented and analyzed. In section 6, we conclude by suggesting how the empirical findings can be used to assist in acting on the lessons that have been learnt from the Kazakh banking crisis.

\footnotetext{
${ }^{1}$ In the extant literature Kazakh banks have featured in a number of cross country studies on the affect of financial development on banking efficiency (e.g. Turk Ariss, 2010; De Haas et al., 2010; Fries and Taci, 2005). The first of these studies analyses banking efficiency across 60 countries whereas the latter study uses a sample of banks in 15 countries. These studies provide a regional picture of bank efficiency although it is debatable if it makes sense to compare the findings of such studies because often the samples are very different. Interestingly, in the latter study, on average, Kazakh banks are the most efficient in the sample. This finding provides further motivation for an efficiency analysis which focuses exclusively on Kazakh banks.
} 


\section{Kazakh Banking Sector Development}

A modern banking system typically has a decentralized two-tier structure with second-tier commercial banks that are independent of the upper-tier central bank. In 1987, several years prior to the collapse of Soviet Union, the Soviet government formally reorganized the monobank into a two-tier banking system. The State Bank (Gosbank) acted as the central bank. The second tier consisted of specialized commercial banks which were responsible for providing financial services to state-owned enterprises. Many branches of the quasi-independent commercial banks severed ties with their parent bank and formed autonomous banking units. In addition, privately-owned banks and financial institutions were allowed to enter the industry. This resulted in a rapid increase in the number of registered commercial banks.

In 1991, Kazakhstan inherited this quasi two-tier banking system with 72 second-tier banks. In 1993, Kazakhstan left the ruble area and introduced its own currency (Kazakh tenge, KZT). In the same year the Gosbank was reorganized and the Kazakh central bank, the National Bank of the Republic of Kazakhstan (NBK), was formed. Initially, as is the case in most transition countries, the new central bank had quite liberal licensing policies which in conjunction with shortcomings in the legal framework and the supervisory system fostered further growth in the number of undercapitalized and potentially nonviable banks. By 1994 the number of banks had peaked at 191. This rapid growth of the banking system, however, did not result in an increase in financial intermediation and competition. Hoelscher (1998) posits that there are four reasons for this: (i) in some parts of the country banking was highly concentrated; (ii) there were established working relationships between some banks so competition was not likely to materialize between these banks; (iii) the formation of financial-industrial groups deterred entry; (iv) some banks were set up not to compete but for other reasons e.g. to obtain subsidized credit from the NBK.

In the 1990s Kazakhstan experienced severe macroeconomic and financial instability. GDP fell by over 25\% over the period 1992-94 and in 1994 inflation was 1, 160\%. Also, private sector confidence in the banking sector dissipated rapidly. This is evident because the deposit base as a share of GDP fell from $72 \%$ in 1994 to less than 5\% in 1996. This coincided with the NBK presiding over a series of reforms of the banking and financial system. The reforms included, the introduction of liquidation proceedings which enabled NBK to initiate the liquidation of failing banks. Banking supervision was also tightened and involved more comprehensive on-site inspections, tighter licensing agreements and stricter capital requirements. This resulted in an increase in license withdrawals and a marked fall in the number of new bank registrations. This is borne out by the sharp fall in the number of banks over the period 1995 - 2005 (see Table 1). In 1994 non-performing loans accounted for over $50 \%$ of the system's loan portfolio. In light of this a big part of the reforms involved transferring non-performing loans from banks to three debt resolution companies (the Rehabilitation Bank, RB, the Agricultural Support Fund, ASF, and Exim Bank) which were set up by the NBK (IMF, 1998).

[Insert Table 1] 
Strong economic growth from 2000 - 2007 (over 10\% for some years during this period), which was largely due to growth of the oil sector, fuelled confidence in many sectors of the Kazakh economy. The rapid growth of the Kazakh economy was accompanied by an increase in the capacity of the Kazakh banking system. Financial deepening also increased sharply in Kazakhstan and was well above the levels in most of the former Soviet Union countries and was only slightly below the levels in the EU accession countries (IMF, 2005). To illustrate, the lending of commercial banks as a share of GDP increased from 7\% in 1999 to $67 \%$ in 2007 and over the same period, the ratio of deposits to GDP increased from $8 \%$ to $48 \%$.

Although the credit boom in Kazakhstan was accompanied by an increase in the deposit base, the base was not strong. This is because the growing confidence in the Kazakh banking system and the gradual depreciation of the tenge since 2000 created a strong preference for foreign currency. Moreover, since the demand for credit was growing faster than domestic savings some Kazakh banks, which were rated by international rating agencies, borrowed heavily in international markets at competitive rates to finance mortgages, consumer loans, loans for real estate construction and loans to facilitate international trade. Consequently, the ratio of foreign currency lending to total lending was high. For example, only $10 \%$ of mortgage loans in 2004 were issued in the domestic currency (IMF, 2005). Because of the availability of foreign currency at relatively cheap rates some Kazakh banks increased their holdings of real estate, investments and financial assets abroad. By 2007 the banking sector's external debt was $43.2 \%$ of GDP (Barisitz and Lahnsteiner, 2010). In addition, by the end of 2006 off-balance sheet items had grown to over three-quarters of the banking system's balance sheet assets. Despite strong economic growth in Kazakhstan, the reliance of the banking system on external finance represented a substantial risk which ultimately proved to be excessive.

The sustained credit expansion in Kazakhstan was followed by a severe credit collapse in late 2007. The collapse was severe because the credit bubble had grown so big. Typically a credit bubble in an emerging market is preceded by a credit boom lasting about 3.5 years (IMF, 2004). In the case of Kazakhstan the credit boom lasted longer than is typically the case which fuelled the growth of the credit bubble. The Kazakh credit crisis was primarily due to moral hazard problems in the Kazakh banking sector because too many risky loans, in particular mortgages, were issued in the credit boom. The U.S. subprime and global financial crises made foreign investors more risk averse, there was large scale deleveraging by foreign investors and there was a shift away from investing in real estate, all of which exacerbated the problems in the Kazakh banking sector. This is because Kazakh banks were heavily dependent on external finance and a large share of Kazakh banks' loan portfolios were financing real estate projects. Kazakh banks were unable to roll over their external debts and service sizeable maturing liabilities. Confidence in the Kazakh banking sector declined and consequently, in 2008 there was a marked fall in household deposits as a share of GDP (see Table 2).

[Insert Table 2]

Accordingly, domestic liquidity conditions tightened significantly in 2007. To support the liquidity of banks, the NBK reduced reserve requirements and arranged large scale liquidity 
provisions through foreign exchange swaps, repo agreements and early redemption of NBK notes. Furthermore, the NBK intervened heavily in the foreign exchange market to prop up the tenge. The main vehicle for crisis relief in the Kazakh banking sector and real economy was a newly formed state entity, Samruk-Kazyna (SK). At the end of 2007 the assets on SK's consolidated balance sheet totalled $\$ 47$ billion (equivalent to $45 \%$ of GDP), which were largely from the Oil Fund (IMF, 2009b). ${ }^{2}$

Following the sharp depreciation of the Russian ruble, the tenge was devalued by almost a fifth in February 2009 to improve the competitiveness of Kazakh exports, save on foreign currency reserves and decrease the pressure on the domestic currency. After the devaluation of the tenge, the debt-servicing burdens of Kazakh banks, which were already struggling to refinance foreign funding, increased further. In 2009 - 10 two large domestically owned banks (the BTA and Alliance banks) and two smaller domestically owned banks (Temir Bank and Astana Finance) stopped making principal payments and were forced to restructure their external obligations (IMF, 2010). Consequently, international rating agencies downgraded the debt ratings of systemically important Kazakh banks. In addition, by 2009 the ratio of nonperforming loans to total lending across the sector had increased to $38 \%$ compared to $7 \%$ in 2007. The sharp increase in non-performing loans and hence the rise in loan loss provisions resulted in almost zero industry profit in 2008. Large losses were expected in future years because in 2008 the gap between banks' assets and liabilities was equivalent to $6 \%$ of GDP.

In response to the crisis in the Kazakh banking sector, the state holding company, SK, provided direct equity support to the three largest ailing banks so they could recapitalize. In February 2009, SK acquired a majority stake in BTA (75\%), the country's largest bank. It also acquired minority stakes in the second and third largest banks, Halyk Bank (21\%) and Kazkommertsbank (20\%), respectively. In total SK provided $\$ 2.2$ billion of support to the three largest banks. A further $\$ 220$ million was set aside to purchase more equity in Halyk Bank and \$200 million was earmarked for a stake in Alliance, the fourth largest bank. SK used another $\$ 4$ billion to support struggling real estate and construction projects, and to finance SME lending and development of the agricultural and industrial sectors. Furthermore, SK made deposits in the Kazakh banking system which amounted to $1.6 \%$ of GDP.

In 2009 BTA and Alliance had massive negative equity which amounted to $12.6 \%$ of GDP and was the reason total banking capital was negative ( -915 million KZT). Although BTA and Alliance were nationalized they defaulted on their foreign liabilities because the Kazakh government only agreed to guarantee domestic liabilities. Despite this the dire forecasts of bank runs never materialized. In the second half of 2009 the Kazakh banking sector started to recover and the recovery gathered momentum in 2010. This is because: (i) oil and commodity prices rebounded; (ii) real output growth remained positive because of looser monetary policy; (iii) the debts of BTA and Alliance which they either defaulted on or restructured did not unduly affect the domestic deposit base (IMF, 2010); (iv) limits were placed on banks' foreign exchange borrowing.

\footnotetext{
${ }^{2}$ The Oil Fund was set up in 2001 to manage Kazakhstan's liquid surplus oil revenue to avoid a situation resembling the Dutch Disease (IMF, 2001).
} 
The recovery represented a period of relative stability in the Kazakh banking system which fostered a steady improvement in liquidity and gradual rebuilding of the capital base. Nevertheless, the volume of non-performing loans as a share of total lending remains high by international standards which must be addressed to continue the rehabilitation of the Kazakh financial system.

\section{Empirical Methodology}

The relationship between the quality and risk of the loan portfolio and economic and technical performance in the Kazakh banking industry is investigated using the parametric stochastic frontier framework. Technical efficiency is analyzed by fitting an input distance function, whereas economic efficiency is analyzed by estimating cost, revenue and profit (standard and alternative) functions. The modeling assumes that a bank's observed deviation from the frontier is caused by random noise $(v)$ and also possibly inefficiency $(u)$. The former is a symmetric normally distributed idiosyncratic error term which captures sampling, measurement and specification error. Inefficiency, on the other hand, is a one-sided non-negative error term.

We model the industry best practice frontiers by accounting for, firstly, inter-bank heteroscedasticity in $u$ à la Kumbhakar et al. (1991) and Battese and Coelli (1995) and secondly, unobservable heterogeneity in banks' technologies by following the 'true SFA' framework (Greene, 2005). In particular, we model the latent heterogeneity in banks' technologies using bank fixed effects. The observable heterogeneity in banks' technologies is modeled by allowing bank-specific characteristics to influence the frontier. This specification is based on a single-step estimation procedure. It is therefore free from the bias associated with two-stage SFA techniques (Wang and Schmidt, 2002).

In this section for sake of brevity we only discuss the cost function and its properties. See Appendix A. 1 for the corresponding discussion pertaining to the input distance, revenue, standard profit and alternative profit functions. ${ }^{3}$ The fitted cost functions (i.e. a function for the minimum cost required to produce outputs given the input prices), $c(y, w)$, for $N$ banks over $T$ periods are of the following form:

$$
\ln \left(C_{i t} / w_{K i t}\right)=\gamma+\lambda_{i}+T L\left(y_{i t}, w_{i t} / w_{K i t}\right)+\rho^{\prime} z_{i t}+v_{i t}+u_{i t} \quad i=1, \ldots, N \quad t=1, \ldots, T
$$

where $C_{i t}$ is the observed cost of bank $i$ at time $t ; y_{i t}$ is a vector of output levels; $w_{i t}$ is a vector of input prices; $z_{i t}$ is a vector characterizing the quality and risk of bank $i$ 's loan portfolio at time $t$ as well as other bank specific features. The $\lambda_{i}$ parameters are bank fixed effects which

\footnotetext{
${ }^{3}$ Berger and Mester (1997) favor the alternative profit function over the standard specification if: (i) there are substantial unmeasured differences in the quality of services provided by banks because the alternative profit function holds the quantities of outputs constant and captures differences in quality by allowing output prices to vary; (ii) a bank cannot achieve every output scale and product mix because the quantities of its outputs exhibit very little variability; (iii) the banking industry is imperfectly competitive; (iv) there is likely to be measurement error in the data on output prices.
} 
capture the latent heterogeneity of banks which is not explained by the $z$-variables. The $T L$ function in equation (1) represents the technology as the translog approximation of the log of the cost function and is in terms of the output quantities and the normalized inputs prices. ${ }^{4}$ $v_{i t}$ is a symmetric normally distributed idiosyncratic error term and $u_{i t}$ is a measure of how far away bank $i$ 's costs are at time $t$ from the best-practice level associated with the same output quantities being produced under the same conditions. It is assumed that $u_{i t}$ follows a truncated normal distribution with a mean $\mu_{i t}$ specific to each observation. This is a more flexible assumption than assuming that $u_{i t}$ follows a half-normal distribution (see Stevenson, 1980, for further details). The heteroscedastic frontier model assumes that $\mu_{i t}$ is a function of factors specific to bank $i\left(z^{\mu}\right)$. The determinants of the stochastic frontier and $u_{i t}$ are therefore simultaneously estimated. Specifically, the mean of the inefficiency distribution in equation (1) is specified as follows:

$$
\mu_{i t}=\delta_{0}+\delta^{\prime} z^{\mu}+\varepsilon_{i t}
$$

The microeconomic properties of an estimated cost function, $c(y, w)$, are: (i) non-decreasing in outputs, $y, \partial \ln c(y, w) / \partial \ln y_{m} \equiv e y_{m} \geq 0, m=1, \ldots, M$; (ii) non-decreasing in input prices, $w, \partial \ln c(y, w) / \partial \ln w_{k} \equiv e w_{k} \geq 0, k=1, \ldots, K$; (iii) homogeneity of degree one in input prices, $w, c\left(y, w / w_{K}\right)=c(y, w) / w_{K}$; (iv) a concave and continuous function in inputs prices, $w$.

\section{Data}

We use rich monthly data obtained from the Agency of the Republic of Kazakhstan on the Regulation and Supervision of the Financial Market and Financial Organizations for the period March 2007- December 2010. ${ }^{5}$ Using this data we analyze monthly changes in the performance of Kazakh banks during the financial crisis. The data includes financial, ownership and prudential information for 37 second-tier commercial banks. The panel is unbalanced and consists of 1,566 observations covering virtually the entire Kazakh banking industry (99.7\%). Only a few small new banks were omitted due to zero values in their deposit and/or loan accounts.

We follow the Sealey and Lindley (1977) intermediation approach. Accordingly, the intermediate deposits of commercial banks are split into various categories of earning assets. The inputs in the banking production process are fixed capital (Fixed assets, $x_{1}$ ), deposits (Clients' deposits, $x_{2}$ ) and labor (Personnel expenses, $x_{3}$ ). The outputs in the production process reflect both the lending and non-lending activities of banks. In particular, the outputs are: total customer loans (Customer loans, $y_{1}$ ), investment securities and other securities (Investments, $y_{2}$ ), off-balance sheet items which is included as an output to capture banks' non-traditional activities $\left(O B S, y_{3}\right){ }^{6}$ The data is expressed in real terms at March 2007 prices

\footnotetext{
${ }^{4}$ The translog functional form is used in the model specification as it is more flexible than linear functions and captures cost (profit) behaviour of banks better. We thank the anonymous referee for the note.

${ }^{5}$ In May 2011, the NBK took over the responsibilities of the Agency through the newly formed Committee for the Control and Supervision of the Financial Market and Financial Organizations.

${ }^{6} O B S$ includes total contingent claims which contain letters of credit, guarantees, deposits and loans placed
} 
using the monthly CPI index which was obtained from the Agency of Statistics of the Republic of Kazakhstan.

In the cost and profit function specifications we use three input prices: the cost of physical capital (Price of fixed assets, $w_{1}$ ) which is calculated as the ratio of depreciation charges to the value of fixed assets; the cost of borrowed funds (Price of clients ${ }^{\prime}$ deposits, $w_{2}$ ) which is taken to be the ratio of interest expenses on clients' deposits to the volume of clients' deposits; the cost of labour (Price of labor,$w_{3}$ ) which is expressed as the ratio of personnel expenses to total assets. The output prices used in the revenue and profit functions are: the price of loans (Price of customer loans, $p_{1}$ ) which is calculated by dividing interest income from loans by total customer loans; the price of other earning assets (Price of investments, $p_{2}$ ) which is expressed as the ratio of interest income on investments and securities to the volume of investments and securities; the price of OBS items (Price of $O B S, p 3$ ) which is calculated by dividing income generated from OBS activity by the volume of OBS items.

We capture the quality and riskiness of a bank's lending using two categorizations of its loan portfolio. Both categorizations split a bank's loan portfolio into standard, doubtful and bad loans. The first categorization is based on the volume of loans whereas the second uses provisions for loan losses. In both cases there are a further five sub-categories of doubtful loans. Doubtful loans are categorized according to the score for the loan contract, where the least risky doubtful contracts are placed in Category 1 and the most risky are in Category $5 .^{7,8}$ Using the first categorization, the quality and riskiness of a bank's loan portfolio is captured using the ratio of the volume of loans in each category to total lending. Similarly, using the second categorization quality and riskiness is modeled using the ratio of loan loss provisions for each category to total loan loss provisions. It is important to note that there is potential endogeneity issue related to input prices, risk variables and profit. The level of input/output prices and banking risk are not completely exogenous because they are to some extent chosen by the bank as part of the bank's management policy. Hence, the possible endogeneity of these variables can bias the coefficient estimates. Therefore, as noted by Berger and Mester (1997), the presented analyses is suggestive but not conclusive.

Along with the risk variables, Z-score of the analyzed banks is included in the analysis to take into account the volatility of earnings. It is calculated as a ratio of the sum of the return on assets $\left(R O A_{i t}\right)$ and the capital ratio $\left(C A R_{i t}\right)$ divided by the standard deviation of the return on assets over the analyzed period between March 2007 to Dec. $2010\left(S D R O A_{i}\right)$ : i.e. $Z-$ score $_{i t}=\left(R O A_{i t}+C A R_{i t}\right) / S D R O A_{i}$. In Table 3, we present the descriptive statistics for the inputs, outputs, prices, loan quality variables and the Z-score.

\section{[Insert Table 3]}

in the future, possible claims on bills, and the purchase and sale of financial derivatives.

${ }^{7}$ The score for a loan is calculated according to, among other things: the financial condition and rating of the borrower; the quality of the collateral; any extensions to the repayment period; any write-offs of the borrower by other creditors; any overdue payments.

${ }^{8}$ Details of the five categories of doubtful loans are as follows: Category 1- substandard loans with current payments; Category 2 - substandard loans with payments in arrears; Category 3 - unsatisfactory loans with current payments; Category 4 - unsatisfactory loans with payments in arrears; Category 5 - doubtful loans. 
We also include a number of other $z$-variables to capture the effect of: (i) bank regulation and supervision i.e. dummies which take a value of 1 if a bank complies with prudential capital requirements (Prudential_Req) and limits on foreign currency positions (ForCur Limits); (ii) state ownership vis-à-vis private ownership i.e. a State dummy which takes a value of 1 if a bank is state owned; (iii) bank size as a proxy for international financial intermediation and scale of performance i.e. Small, Medium and Large bank size dummies; ${ }^{9}$ (iv) negative equity i.e. a Negative Equity dummy which takes a value of 1 if a bank has had negative equity at any point over the sample period.

\section{Results and Analysis}

This section consists of four sub-sections. In 5.1 we present the fitted models and discuss the returns to scale estimates. In 5.2 we present and analyze the estimates of economic efficiency (cost, revenue, standard profit and alternative profit efficiencies) and technical efficiency (inputoriented efficiency) over the sample period using each categorization of the quality and risk of the loan portfolio. Furthermore, in 5.3 and 5.4 we discuss the findings on the impact of each categorization of the quality and risk of the loan portfolio on the industry best practice frontiers and the inefficiency estimates. To put the effect of each categorization on the best practice frontiers and the inefficiencies into context we also discuss the effect of other $z$-variables.

\subsection{Returns to Scale}

The estimation results for the two model specifications for each function- model 1 (quality and risk of the loan portfolio modeled using the volume of loans categorization) and model 2 (quality and risk of the loan portfolio modeled using the loan loss provisions categorization) are presented in Appendix A.2. We can see from these results that the input, output and corresponding price elasticities for all the fitted functions apart from the standard profit function have the expected signs where significant, implying that the monotonicity conditions are not disproved at the sample mean. The returns to scale estimates at the sample mean from the cost function (2.17 and 1.76 for models 1 and 2, respectively), input distance function (3.31 and 3.01 for models 1 and 2, respectively), revenue function (2.15 and 2.04 for models 1 and 2 , respectively) and alternative profit function (2.78 and 3.17 for models 1 and 2, respectively) are in some cases considerably greater than unity i.e. an average Kazakh bank operates at increasing returns to scale in all eight cases. ${ }^{10}$ The above scale elasticities are computed at the

\footnotetext{
${ }^{9}$ The bank size dummies are based on a size categorization of banks according to total assets. In particular, banks are classified as: small - if their total assets are less than 10,000, $000(000 \mathrm{~s}) \mathrm{KZT}$; medium - if their total assets are between 10,000,000 (000s) KZT and 1,000,000,000 (000s) KZT; large - if their total assets exceed $1,000,000,000(000 \mathrm{~s}) \mathrm{KZT}$.

${ }^{10}$ Cost (Alternative profit) returns to scale $(R T S)$ can be defined as the percentage change in cost (alternative profit) as a result of a one percent increase in all outputs. In other words, cost (alternative profit) $R T S$ are equal to the reciprocal of the sum of the cost (alternative profit) elasticities with respect to the outputs i.e. $\left(\sum e_{y}\right)^{-1}$. It follows therefore from a fitted input distance function that $R T S_{I D F}=-\left(\sum e_{y}\right)^{-1}$. Revenue $R T S$ can be defined as the percentage change in revenue when there is a one percent increase in all inputs i.e.
} 
sample mean of the data and are therefore unweighted average measures. A country's banking industry, however, is generally characterized by a large number of small banks where the scale elasticity is high and a small number of large banks where the scale elasticity is low, possibly below one. Therefore, the above unweighted scale elasticities are most probably overestimates due to a large number of small banks in the sample as we use data for virtually the entire Kazakh banking industry. Asset weighted average scale elasticities would be lower than the corresponding unweighted elasticities.

Interestingly, revenue returns to scale from models 1 and 2 are very similar. In contrast, there is a marked change in cost, alternative profit and input distance economies of scale depending on whether the measure of loan portfolio quality and risk is the volume of loans categorization or the loan loss provisions categorization. The robustness or sensitivity of economies of scale to the measure of loan portfolio quality and risk is most probably because the economic frontiers are sensitive to the affect of managerial discretion on loan loss provisions which is a tool to manipulate bank profit. At the sample mean, investments and OBS items are not the source of the difference between cost returns to scale for models 1 and 2 and between the estimates of alternative profit returns to scale because the parameter estimates for these outputs are all small. Our results suggest that the large difference between the cost returns to scale and the alternative profit returns to scale from models 1 and 2 is due to financial intermediation activities. More specifically, we attribute the differences in cost returns to scale and alternative profit returns to scale to differences in the marginal effects of customer loan issuance in models 1 and 2.

\subsection{Efficiency Results}

Average economic and technical efficiency scores for Kazakh banks over the sample period are reported in Table 4. In general, the average efficiency scores over the sample period using the volume of loans categorization range from $69 \%-88 \%$, the exception being the average efficiency score from the revenue function (47\%). More specifically, the average efficiency score from the cost model over the sample period suggests that the costs of an average bank are $12 \%$ above the best practice level. Similarly, mean profit efficiency scores over the sample period of $79 \%$ and $80 \%$ suggest that, on average, banks make about $80 \%$ of the profit which the best practice bank would make under the same conditions.

\section{[Insert Table 4]}

The Kruskal-Wallis tests of the null that the efficiency scores from corresponding models (e.g. the two cost models) in Table 4 do not differ is always rejected. That said, the difference between the corresponding average standard profit and alternative profit efficiencies is negligible. Over the sample period there is a $14 \%$ difference between the average efficiency scores from the cost functions and there is a $6 \%$ difference between the average efficiency scores from the $R T S_{R F}=-\left(\sum e_{x}\right)^{-1}$. 
revenue functions. The corresponding average input-oriented and average revenue efficiency scores are characterized by a somewhat downward trend which is more evident in profit efficiency scores. A downward trend in average economic efficiency and average technical efficiency is to be expected over the financial crisis.

Average cost efficiencies are presented in Figure 1. The plot suggests that although there is a considerable difference between the average cost efficiencies from models 1 and 2, there is little difference between the average cost efficiencies at the start of the sample period compared to the end of the period. It is evident from Figure 2 that this is also the case for the average input-oriented and the average revenue efficiencies. It is apparent, however, that the average efficiencies from the standard and alternative profit functions at the start of the sample period are well above the levels which we observe at the end of the sample period. Summarizing, this suggests that the financial crisis only had a sustained detrimental effect on the average efficiencies from the standard and the alternative profit functions.

\section{[Insert Figures 1 and 2]}

We can see that average technical efficiency from model 1 is well above that from model 2 for the entire sample period. Conversely, average revenue efficiency from model 2 is much higher than that from model 1 throughout the sample period. The average profit (standard and alternative) efficiencies from models 1 and 2, however, are very similar over the whole sample period. It is also evident that the average profit (standard and alternative) efficiencies are much more volatile than the other average efficiencies. That said, we observe at least one spike in the other average efficiencies. Over the course of the financial crisis there are large isolated temporary changes in the average efficiencies from the cost, revenue and input distance functions. For example, the average cost efficiency from model 1 fell to $66 \%$ in August 2008. Average cost efficiency from model 1 once again fell to $64 \%$ in October 2009 but on this occasion is was the result of a steady decline over several months. In October 2009, the average cost efficiency from model 2 had fallen to $79 \%$. It is not surprising that the lowest average cost efficiencies are observed in 2009 because it was a very turbulent year for the Kazakh banking industry. As was noted in Section 2, in 2009 the level of non-performing loans increased dramatically and in July 2009 the equity capital of the banking system was negative.

The BTA and Alliance cost efficiencies from models 1 and 2 are presented in Figures 3 and 4. The cost efficiencies add credence to the anecdotal evidence on the troubles of BTA and Alliance during the financial crisis. Apart from the sharp fall in the BTA cost efficiency scores in September 2008, BTA was performing well relative to the industry average up until April 2009, which was when BTA defaulted on its foreign liabilities. From April 2009, the cost efficiency of BTA from both models deteriorates rapidly over a period of several months. By July 2009, BTA's ratio of bad loans to total lending (54\%) was the highest in the industry. According to the cost models, in June 2010 BTA was the worst performing bank in the industry with an efficiency score of $6 \%$ from model 1 and $31 \%$ from model 2 .

[Insert Figures 3 and 4] 
The Alliance cost efficiencies over the sample period follow similar paths to those for BTA. It should be noted, however, that although the Alliance and BTA cost efficiencies started to decline in April 2009, the decline was much more sustained for BTA. This is evident because the Alliance cost efficiencies started to rise in November 2009, whereas the BTA cost efficiencies did not begin to rise until July 2010. This corroborates the view that BTA suffered more during the financial crisis than Alliance.

\subsection{Impact of Loan Portfolio Quality and Risk on the Frontiers}

The estimates of the effect of each $z$-variable on the industry best practice frontiers and the bank inefficiencies are presented in Tables 5 and 6 . Specifically, the estimates in Table 5 are for model 1 (i.e. when loan portfolio quality and risk is measured using the volume of loans categorization) and the estimates in Table 6 are for model 2 (i.e. when loan portfolio quality and risk is measured using the loan loss provisions categorization). A cursory glance at the results indicates that the Medium bank size dummy has been omitted to avoid perfect collinearity. This means that the effects of Small and Large banks are relative to the effect of the Medium size category. Other $z$-variables which are omitted for the same reason are: the ratio of the volume of doubtful loans in the fifth category to the total volume of doubtful loans; the ratio of loan loss provisions in the fifth category to total loan loss provisions; the ratio of the volume of standard loans to the volume of total lending; the ratio of loan loss provisions for standard loans to total loan loss provisions.

\section{[Insert Tables 5 and 6]}

Turning our attention to the effects of the $z$-variables on the industry best practice frontiers (see the top panels of Tables 5 and 6 ). It is evident that the ratio of the volume of bad loans to the volume of standard loans has a small effect on each of the frontiers, which is similar in magnitude in corresponding models e.g. both the cost functions. It is surprising that all the $B L / S L$ parameters are so small but this is because the effect of the quality and risk of the loan portfolio is being captured by other variables. The large and significant effects of other variables which measure the quality and risk of the loan portfolio often vary between corresponding models. For example, it is apparent that relative to $D L$ Category $5 / D L, D L$ Category $3 / D L$ has a large negative effect on the revenue frontier and relative to $R D L$ Category $5 / R D L, R D L$ Category $3 / R D L$ has a small positive effect on the revenue frontier. Also, we can see that $D L / T A$ has quite a large negative effect on the alternative profit frontier, whereas $R D L / T A$ has quite a large positive effect on the alternative profit frontier.

Interestingly, the fitted models suggest that if there is an increase in $B L / T A$, there will be a big improvement in the cost and input distance best practice frontiers. Also, we find that an increase in $R B L / T A$ will have a large positive effect on the alternative profit best practice frontier. All these findings are consistent with 'skimping' behavior which is where banks allocate less resources to loan screening because they have short run objectives of cost minimization and revenue maximization. This can serve to improve cost and revenue performance in the 
short term but in the medium to long term it will have a detrimental effect on cost and revenue performance. 'Skimping' has also been used to explain the findings of other studies of bank performance in both advanced and emerging economies (e.g. Berger and DeYoung, 1997; Wheelock and Wilson, 2000; Delis et al., 2011; Berger et al. 2009). In the other models where $B L / T A$ or $R B L / T A$ are significant the parameters have the expected signs. This suggests that an increase in $B L / T A$ or $R B L / T A$ will have an undesirable effect on industry best practice.

Whereas the effect of the $B L / S L$ variable on the best practice frontiers is similar in magnitude in the corresponding models in Tables 5 and 6 , this if often not the case for other $z$-variables. Negative Equity, for example, has quite a large positive and significant effect on the cost frontier in model 1 but it does not have a significant effect on the cost frontier in model 2. That said, the significant coefficients on Negative Equity consistently suggest that it has a detrimental effect on industry best practice. Furthermore, the significant Small and Large bank size parameters suggest that industry best practice will improve if, relative to the number of medium-sized banks, there are more small and large banks. The $Z-$ score parameter is significant in all functions for both models. In particular, in the input-distance and revenue function for both models it has expected positive impact. That is banks with higher $Z-$ score, i.e. more stable banks with fewer risk, tend to perform better in terms technical and revenue activities. The negative sign of $Z$ - score in the cost function is also expected as it suggests that more stable banks have lower costs. However, when it comes to profit functions, the negative sign is at odds with the expectations but in line with the findings relating to negative equity in the next sub-section. It suggests that less stable banks with higher risks tend to have significantly higher profits.

\subsection{Impact of Loan Portfolio Quality and Risk on Inefficiency}

Moving onto consider the effects of the $z$-variables on economic inefficiency and technical inefficiency (see the bottom panels of Tables 5 and 6 ). It is evident that, in general, where the $D L / T A$ and $R D L / T A$ parameters are significant, the effect on inefficiency is negative. The exception is the positive effect which $R D L / T A$ has on cost inefficiency.

Where the $B L / T A$ parameter is significant, the effect on inefficiency is positive. Sun and Chang (2011) also find a positive relationship between credit risk and inefficiency for banks in emerging Asian countries. Specifically, we find that $B L / T A$ has the biggest positive effect on alternative profit inefficiency and smaller positive effects on cost inefficiency and revenue inefficiency. This is most probably because, as Berger et al. (2009) note, profit efficiency is a more encompassing measure of economic performance and incorporates both cost and revenue efficiency. Furthermore, it is interesting to note that in both model specifications foreign ownership has a significant negative effect on technical inefficiency and a significant positive effect on cost inefficiency. There is no consensus in the banking performance literature on whether foreign owned banks are more efficient than their domestic counterparts. For example, Jemric and Vujcic (2002) find that foreign owned banks in Croatia are far more efficient than domestic banks. Similarly, Weill (2003) finds that foreign owned banks in Poland and the 
Czech Republic are more efficient than domestic banks, which he attributes to foreign banks having more human capital and better corporate governance. Conversely, other studies such as Hasan and Marton (2003) find that foreign banks in transition economies are less efficient than domestic banks. Lensink et al. (2008) analyze the performance of over 2000 banks in 105 countries and conclude that foreign banks are less efficient than domestic banks. They attribute the difference between the efficiency of domestic and foreign banks to banking system conditions and the economic climate in the relevant countries.

Since the most distressed banks in Kazakhstan were domestic banks, our finding that foreign owned banks were less cost efficient during the financial crisis could well be because they did not engage in 'skimping'. If banks skimp they are likely to allocate fewer resources to underwriting and monitoring loans, thereby saving costs in the short term. Having said this, the quality of the loan portfolio declines because of 'skimping' and the subsequent rise in non-performing loans is likely to increase a bank's costs in the medium to long term. Our results are consistent with foreign banks allocating more resources than domestic banks to screening loans, appraising collateral and monitoring borrowers, rather than 'skimping' on these costs. This would explain why over the sample period foreign banks have a lower ratio of non-performing loans to total lending.

Both of the fitted input distance functions suggest that, relative to medium-sized banks, small banks are more technically inefficient. The second specification of the revenue function also suggests that small banks are relatively inefficient. In contrast, the second specification of the standard profit function and the alternative profit function suggest that large banks are more inefficient than their medium-sized counterparts. Comparing and contrasting all the above findings on the effect of bank size on inefficiency, with the estimates of the effect of bank size on the frontier suggests that an improvement in industry best practice (i.e. the availability of better technology) does not necessarily lead to more efficient bank performance.

The Negative Equity parameter is significant in the first specification of the input distance function. The Negative Equity parameters are also significant in the second specification of the cost function and revenue function. As expected all the significant Negative Equity parameters are positive, which suggests that Negative Equity leads to more inefficient performance. This finding could well be a feature of banking performance during the financial crisis because in an earlier study by Hasan and Marton (2003) a positive relationship between the level of equity and inefficiency is observed. Interestingly, our results suggest that Negative Equity does not affect standard profit inefficiency, whereas we noted in 5.3 that Negative Equity has a detrimental effect on the standard profit frontier in both of the fitted models and on the alternative profit frontier in the second specification. This suggests that the large negative equity of a small number of banks during the financial crisis affected profit best practice at the industry-wide level but not the profit inefficiency of individual banks.

Turning our attention to the effect on bank performance of compliance with prudential capital requirements and limits on foreign currency positions. In general, our findings suggest that compliance with prudential capital requirements or limits on foreign currency positions 
has no implications for banking performance. There are, however, four interesting exceptionsthe positive and significant ForCurr Limits parameter in the cost function (Model 1), and the significant positive coefficient on ForCurr Limits in the second specification of the input distance function and negative coefficients in the revenue and standard profit function in Model 2 .

The positive and significant ForCurr Limits parameter in the fitted model 1 specification of the cost function suggests that more risk averse banks which comply with the limits on foreign currency positions are more cost inefficient. Being more cost efficient in the short term by not complying with the regulations is consistent with banks being less risk averse and 'skimping', which will ultimately erode the quality of the loan portfolio. Hellmann et al. (2000) develop a theoretical model which shows that financial liberalization gives rise to such problems. The intuition behind their model is as follows. Financial liberalization promotes entry to the banking industry which intensifies competition and erodes bank profit. The capitalized value of expected profits (i.e. the franchise value) falls and there is less incentive to issue good loans to preserve the franchise value. In their model banks choose between investing in a prudent asset which yields a high expected return or investing in a gambling asset which yields a very high return if the gamble pays-off but if it doesn't depositors bear the cost of the investment. The conclusion which is reached from the model is that following financial liberalization there will be a bigger incentive to invest in gambling assets. This model and, in particular, the scenario where gambles do not pay-off is akin to developments in the Kazakh banking sector during the financial crisis.

Upon receiving favorable credit ratings from major international credit agencies, many Kazakh banks engaged in a range of new foreign exchange activities. The second specification of the input distance function suggests that banks are more technically inefficient if they are less risk averse and exceed limits on foreign currency positions. Along similar lines, the second specification of the revenue and standard profit functions suggests that banks which exceed limits on foreign currency positions are more inefficient. This is most probably because more risk averse banks which comply with limits on foreign currency positions are less exposed to risky foreign currency operations.

\section{Lessons from the Kazakh Experience}

Using rich monthly data for virtually the entire Kazakh banking industry over the financial crisis, SFA is applied to the financial intermediation approach to fit a number of functions. Among other things, from the fitted functions we estimate the effects of two measures of the quality and riskiness of the loan portfolio on the industry best practice frontiers and the technical and economic inefficiencies of individual banks. The determinants of the bank technologies and bank inefficiencies shed light on Kazakh bank behavior over the financial crisis. For example, we find that an increase in the volume of bad loans as a ratio of total lending has a desirable effect on the cost, input-distance and alternative profit frontiers, all of which is consistent with 
the 'skimping' hypothesis. In the loan loss provisions specifications, an increase in the ratio of reserves on bad loans to total reserves has the expected significant detrimental effect on the cost, input distance and revenue frontiers, which is at odds with the 'skimping' hypothesis. Given there is a lot of anecdotal evidence of 'skimping' by Kazakh banks during the financial crisis and non-performing loans is still a big concern in the Kazakh banking industry, the ratio of the volume of bad loans to total lending, rather than the ratio of reserves on bad loans to total reserves, should be used by the regulatory authorities to monitor non-performing loans. To conclude, an empirical analysis of Kazakh banking efficiency using non-parametric frontier models with bootstrapping would be a worthwhile and interesting area for further work.

\section{Acknowledgements}

The authors would like to thank an anonymous referee for constructive comments which helped to improve the paper substantially.

\section{References}

Altunbas, Y., M. Liu, P. Molyneux and R. Seth (2000): 'Efficiency and risk in Japanese banking'. Journal of Banking and Finance, Vol. 24, pp. 1605-1628.

Barisitz, S. And M. Lahnsteiner (2010): 'From stormy expansion to riding out the storm: Banking development in Kazakhstan'. Austrian Central Bank Financial Stability Report, Issue 19, pp. 62-71.

Battese, G. E. and T. J. Coelli (1995): 'A model for technical inefficiency effects in a stochastic frontier production function for panel data'. Empirical Economics, Vol. 20, pp. 325-332.

Berger, A. N. and R. DeYoung (1997): 'Problem loans and cost efficiency in commercial banks'. Journal of Banking and Finance, Vol. 21, pp. 849-870.

Berger, A. N., I. Hasan And M. Zhoud (2009): 'Bank ownership and efficiency in China: What will happen in the world's largest nation?' Journal of Banking and Finance, Vol. 33, pp. 113-130.

Berger, A. N. And L. J. Mester (1997): 'Inside the black box: What explains differences in the efficiencies of financial institutions?' Journal of Banking and Finance, Vol. 21, 895 - 947.

Brissimis, S. N., M. D. Delis and N. I. Papanikolaou (2008): 'Exploring the nexus between banking sector reform and performance: Evidence from newly acceded EU countries'. Journal of Banking and Finance, 32, pp. 2674-2683.

Chiu, Y-H. And Y-C. Chen (2009): 'The analysis of Taiwanese bank efficiency: Incorporating both external environment risk and internal risk'. Economic Modelling, 26, pp. 456-463.

De HaAs, R., D. Ferreira and A. TaCi (2010): 'What determines the composition of banks' loan portfolios? Evidence from transition countries'. Journal of Banking and Finance, 34, pp. 388-398.

Delis, M. D., P. Molyneux and F. Pasiouras (2011): 'Regulations and productivity growth in banking: Evidence from transition economies'. Journal of Money, Credit and Banking, Vol. 43, pp. 735-764.

Fries, S. AND A. TACI (2005): 'Cost efficiency of banks in transition: Evidence from 289 banks in 15 post-communist countries'. Journal of Banking and Finance, Vol. 29, pp. 55-81.

Greene, W. (2005): 'Reconsidering heterogeneity in panel data estimators of the stochastic frontier model'. Journal of Econometrics, Vol. 126, pp. 269 -303.

HASAN, I. AND K. MARTON (2003): 'Development and efficiency of the banking sector in a transitional economy: Hungarian evidence'. Journal of Banking and Finance, Vol. 27, pp, 2249-2271.

HavrylchyK, O. (2006): 'Efficiency of the Polish banking industry: Foreign versus domestic banks'. Journal of Banking and Finance, Vol. 30, pp. 1975-1996.

Hellmann, T. F., K. C. Murdock and J. E. Stiglitz (2000): 'Liberalization, moral hazard in banking and prudential regulation: Are capital requirements enough?' American Economic Review, Vol. 90, pp. 147165.

Hoelscher D. S. (1998): 'Banking system restructuring in Kazakhstan'. IMF Working Paper WP/98/96.

Hughes, J. P. And L. J. Mester (1993): 'A quality and risk-adjusted cost function for banks: Evidence on the 'Too-Big-to-Fail' doctrine'. Journal of Productivity Analysis, Vol. 4, pp. 292-315.

Iannotta, G., G. Nocera and A. Sironi (2007): 'Ownership structure, risk and performance in the European banking industry'. Journal of Banking and Finance, Vol. 31, pp. 2127-2149. 
International Monetary Fund (1998): 'Republic of Kazakhstan - Recent Economic Developments'. IMF Staff Country Report No. 98/84.

International Monetary Fund (2001): 'Republic of Kazakhstan'. IMF Staff Country Report No. $01 / 20$.

International Monetary Fund (2005): 'Republic of Kazakhstan: Selected Issues'. IMF Staff Country Report No. 05/240.

International Monetary Fund (2009a): 'Initial lessons of the crisis'. Prepared by the Research, Monetary and Capital Markets, and Strategy, Policy and Review Departments.

International Monetary Fund (2009b): 'Republic of Kazakhstan: 2009 Article IV Consultation - Staff Report, Supplement and Public Information Notice on the Executive Board Discussion'. Country Report No. $09 / 300$.

International Monetary Fund (2010): 'Republic of Kazakhstan: 2010 Article IV Consultation - Staff Report, Public Information Notice on the Executive Board Discussion and Statement by the Executive Director for Kazakhstan'. Country Report No. 10/241.

International Monetary Fund (2004): 'Are credit booms in emerging markets a concern?' World Economic Outlook, April, pp. 103-146.

IsIK, I. AND M. K. HASSAN (2002): 'Technical, scale and allocative efficiencies of Turkish banking industry'. Journal of Banking and Finance, Vol. 26, pp. 719-766.

Jemric, I. And B. VujCiC (2002): 'Efficiency of banks in Croatia: A DEA approach'. Comparative Economic Studies, Vol. 44, pp. 169-193.

Kenjegalieva, K., R. Simper, T. Weyman-Jones And V. Zelenyuk (2009): 'Comparative analysis of banking production frameworks in Eastern European financial markets'. European Journal of Operations Research, Vol. 198, pp. 326-340.

Kraft, E. and D. Tirtiroglu (1998): 'Bank Efficiency in Croatia: A Stochastic-Frontier Analysis'. Journal of Comparative Economics, Vol. 26, pp. 282-300.

Kumbhakar, S. C., S. Ghosh and J. T. McGuckin (1991): 'A generalized production frontier approach for estimating determinants of inefficiency in U.S. dairy farms'. Journal of Business and Economic Statistics, Vol. 9, pp. 279-286.

KWAN, S. H. (2003): 'Operating performance of banks among Asian economies: An international and time series comparison'. Journal of Banking and Finance, Vol. 27, pp. 471-489.

Laeven, L. and F. Valencia (2010): 'Resolution of banking crises: The good, the bad, and the ugly'. IMF Working Paper WP/10/146.

Lensink, R., A. Meesters and I. NaAborg (2008): 'Bank efficiency and foreign ownership: Do good institutions matter?' Journal of Banking and Finance, Vol. 32, pp. 834-844.

Mester, L. J. (1996): 'A study of bank efficiency taking into account risk-preferences'. Journal of Banking and Finance, Vol. 20, pp. 1025-1045.

Pasiouras, F. (2008): 'Estimating the technical and scale efficiency of Greek commercial banks: The impact of credit risk, off-balance sheet activities, and international operations'. Research in International Business and Finance, Vol. 22, pp. 301-318.

Sealey, C. and J. T. Lindley (1977): 'Inputs, outputs and a theory of production and cost at depository financial institutions'. Journal of Finance, Vol. 32, pp. 1251-1266.

Stevenson, R. E. (1980): 'Likelihood functions for generalized stochastic frontier estimation'. Journal of Econometrics, Vol. 13, pp. 58-66.

Sun, L. And T. Chang (2011): 'A comprehensive analysis of the effects of risk measures on bank efficiency: Evidence from emerging Asian countries'. Journal of Banking and Finance, Vol. 35, pp. 1727-1735.

Turk Ariss, R. (2010): 'On the implications of market power in banking: Evidence from developing countries'. Journal of Banking and Finance, Vol. 34, pp. 765-775.

Wang, H. AND P. Schmidt (2002): 'One-step and two-step estimation of the effects of exogenous variables on technical efficiency levels'. Journal of Productivity Analysis, Vol. 18, pp. 129-144.

Weill, L. (2003): 'Banking efficiency in transition economies: The role of foreign ownership'. Economics of Transition, Vol. 11, pp. 569-592.

Wheelock, D. C. and P. W. Wilson (2000): 'Why do banks disappear? The determinants of U.S. bank failures and acquisitions'. Review of Economics and Statistics, Vol. 82, pp. 127-138. 
Figures and Tables in the Main Text

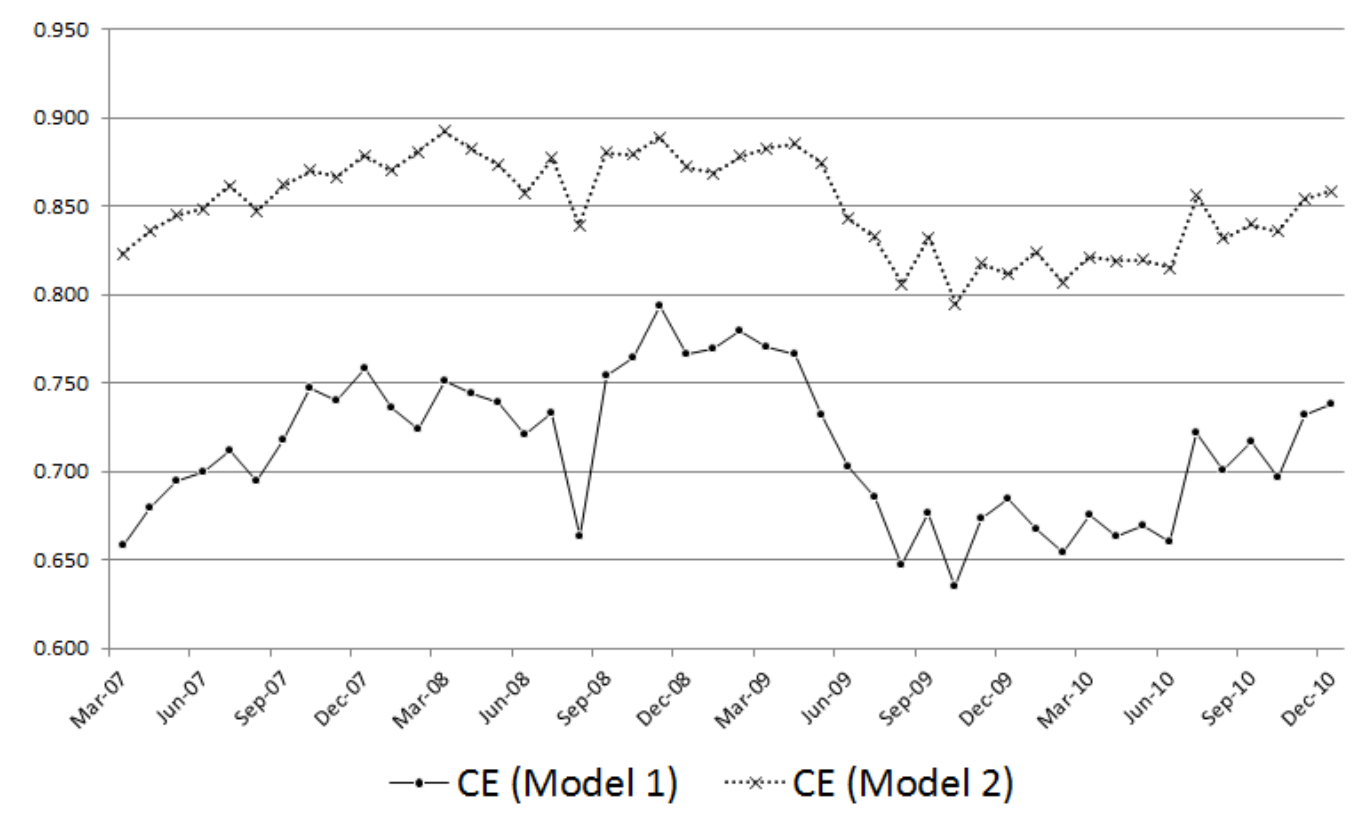

Figure 1: Average cost effciency (CE) of Kazakh banks 

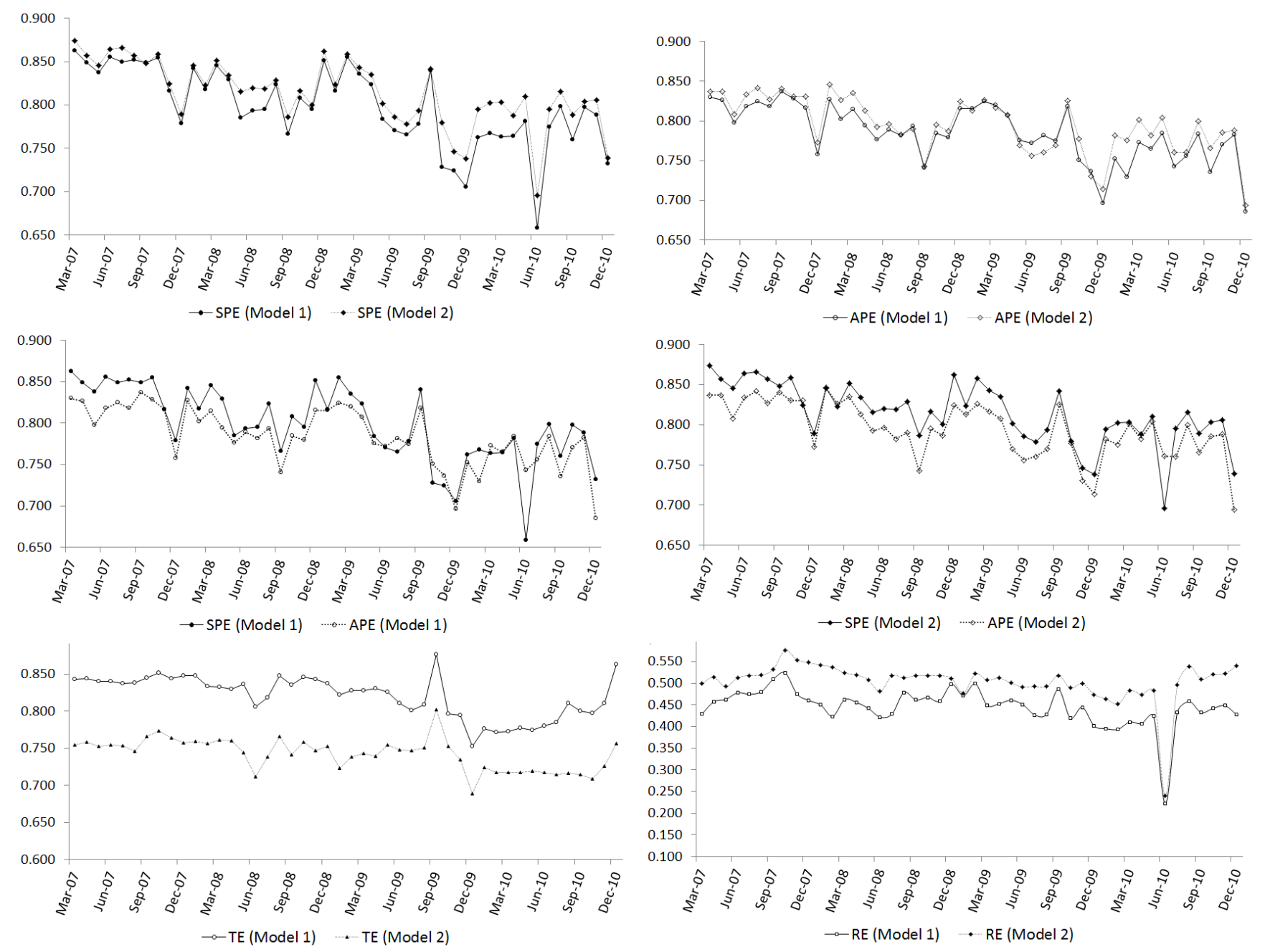

Figure 2: Average economic and technical efficiencies of Kazakh banks 


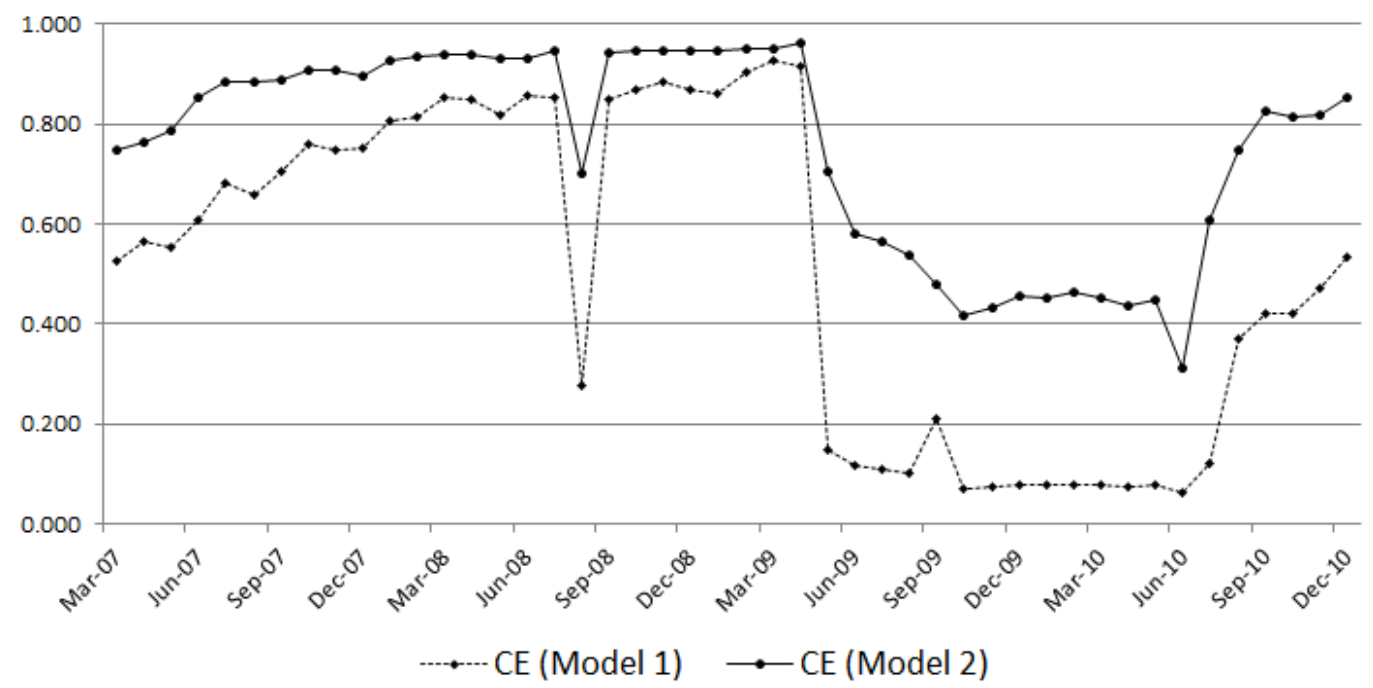

Figure 3: Cost efficiency (CE) of BTA bank

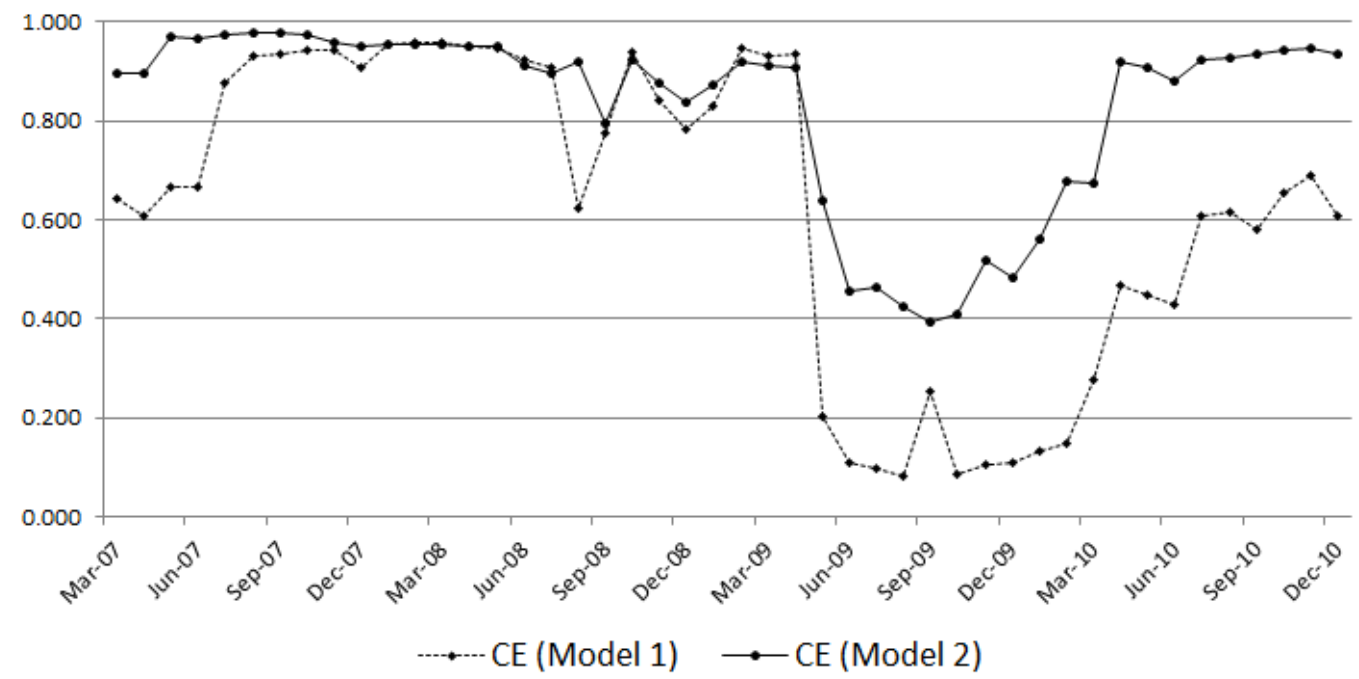

Figure 4: Cost efficiency (CE) of Alliance bank 
Table 1: Structure of the Kazakh banking industry (1995 - 2010)

\begin{tabular}{|c|c|c|c|c|c|c|c|c|}
\hline & 1995 & 1997 & 2000 & 2005 & 2007 & 2008 & 2009 & 2010 \\
\hline Number of commercial banks & 130 & 81 & 48 & 34 & 35 & 37 & 37 & 39 \\
\hline of which have a foreign stakeholder in authorized capital & 8 & 22 & 16 & 14 & 18 & 13 & - & - \\
\hline Number of branches of commercial banks & 1,036 & 582 & 417 & 418 & 352 & 379 & 374 & 365 \\
\hline
\end{tabular}

Notes: - indicates that the data is not available.

Sources: European Bank of Reconstruction and Development; National Bank of Kazakhstan; Financial

Supervision Agency of the Republic of Kazakhstan.

Table 2: Kazakh banking sector indicators

\begin{tabular}{lcccccc}
\hline \hline & 2005 & 2006 & 2007 & 2008 & 2009 & 2010 \\
\hline Total assets (\% of GDP) & 60.6 & 87.5 & 87.8 & 74.1 & 68 & 61.9 \\
Foreign stake (\% of total industry assets) & 7.3 & 5.9 & 15.8 & 15.8 & 23.4 & 34 \\
Loans (\% of GDP) & 41.1 & 59.1 & 66.6 & 57.6 & 60.3 & 46.5 \\
Household deposits (\% of GDP) & 33.9 & 46.5 & 48.2 & 28.6 & 37.6 & 35.2 \\
Return on Assets (\%) & 1.8 & 1.4 & 2.6 & 0.32 & $-1.4^{*}$ & $-1.2^{*}$ \\
Return on Equity (\%) & 14.1 & 14.7 & 22.87 & 2.6 & $-12.6^{*}$ & $-10.6^{*}$ \\
Industry concentration (\%)** & 58.8 & 57.9 & 59.6 & 58.3 & 54.6 & 53.6 \\
Non-performing loans (\% of total loans) & 3.3 & 2.4 & 2.7 & 7.1 & 37.8 & 33.7 \\
\hline
\end{tabular}

Notes: * Excludes Alyans Bank, Temir Bank and BTA bank.

** Concentration is defined as the ratio of assets of the three largest banks to total bank sector assets.

Sources: National Bank of Kazakhstan and Financial Supervision Agency of the

Republic of Kazakhstan.

Table 3: Descriptive statistics for inputs, outputs, prices and loan quality variables

\begin{tabular}{|c|c|c|c|c|c|}
\hline & Mean & St. Dev & & Mean & St. Dev \\
\hline Outputs & \multicolumn{5}{|c|}{ Quality of loans (\%) } \\
\hline Customer loans $\left(y_{1}\right)$ & 158064026 & 337414737 & $D L / T A\left(z_{1}\right)$ & 0.254 & 0.233 \\
\hline Investments $\left(y_{2}\right)$ & 30018124 & 83761696 & DL Category $1 / D L\left(z_{2}\right)$ & 0.458 & 0.332 \\
\hline$O B S\left(y_{3}\right)$ & 226292194 & 540920253 & DL Category $2 / D L\left(z_{3}\right)$ & 0.164 & 0.228 \\
\hline Inputs & & & DL Category $3 / D L\left(z_{4}\right)$ & 0.097 & 0.158 \\
\hline Fixed assets $\left(x_{1}\right)$ & 4628750 & 8698509 & DL Category $4 / D L\left(z_{5}\right)$ & 0.091 & 0.163 \\
\hline Clients' deposits $\left(x_{2}\right)$ & 155545119 & 309677357 & $D L$ Category $5 / D L\left(z_{6}\right)$ & 0.121 & 0.196 \\
\hline \multirow[t]{3}{*}{ Personnel expenses $\left(x_{3}\right)$} & 182666 & 281382 & $B L / T A\left(z_{7}\right)$ & 0.061 & 0.12 \\
\hline & & & $B L / S L\left(z_{8}\right)$ & 0.319 & 3.231 \\
\hline & & & $R D L / T A\left(z_{1}^{*}\right)$ & 0.491 & 0.31 \\
\hline Output prices & & & RDL Category $1 / R D L\left(z_{2}^{*}\right)$ & 0.247 & 0.285 \\
\hline Price of customer loans $\left(p_{1}\right)$ & 0.024 & 0.093 & $R D L$ Category $2 / R D L\left(z_{3}^{*}\right)$ & 0.139 & 0.218 \\
\hline Price of investments $\left(p_{2}\right)$ & 0.07 & 0.462 & RDL Category $3 / R D L\left(z_{4}^{*}\right)$ & 0.133 & 0.187 \\
\hline Price of $\mathrm{OBS}\left(p_{3}\right)$ & 0.087 & 0.694 & $R D L$ Category $4 / R D L\left(z_{5}^{*}\right)$ & 0.134 & 0.192 \\
\hline Input prices & & & RDL Category $5 / R D L\left(z_{6}^{*}\right)$ & 0.275 & 0.276 \\
\hline Price of fixed assets $\left(w_{1}\right)$ & 0.017 & 0.029 & Reserves on bad loans/TA $\left(z_{7}^{*}\right)$ & 0.457 & 0.311 \\
\hline Price of clients ${ }^{\prime}$ deposits $\left(w_{2}\right)$ & 0.024 & 0.392 & & & \\
\hline Price of labor $\left(w_{3}\right)$ & 0.121 & 0.205 & $Z$ - score & 35.025 & 38.806 \\
\hline
\end{tabular}

Notes: DL - doubtful loans; TA - total assets; BL - bad loans; SL - standard loans; RDL - reserves on doubtful loans.

All values are at January 2007 Kazakh tenge prices (000s). 
Table 4: Economic and technical efficiency scores

\begin{tabular}{|c|c|c|c|c|c|}
\hline & $\mathrm{CF}$ & IDF & $\mathrm{RF}$ & SPF & $\mathrm{APF}$ \\
\hline \multicolumn{6}{|c|}{ Model 1 (volume of loans categorization) } \\
\hline 2007 & 0.711 & 0.843 & 0.475 & 0.841 & 0.816 \\
\hline 2008 & 0.741 & 0.834 & 0.453 & 0.812 & 0.791 \\
\hline 2009 & 0.710 & 0.814 & 0.449 & 0.786 & 0.781 \\
\hline 2010 & 0.691 & 0.793 & 0.408 & 0.763 & 0.756 \\
\hline Total sample & 0.713 & 0.819 & 0.444 & 0.798 & 0.784 \\
\hline \multicolumn{6}{|c|}{ Model 2 (loan loss provisions categorization) } \\
\hline 2007 & 0.854 & 0.758 & 0.526 & 0.849 & 0.784 \\
\hline 2008 & 0.875 & 0.749 & 0.517 & 0.825 & 0.826 \\
\hline 2009 & 0.845 & 0.743 & 0.498 & 0.803 & 0.802 \\
\hline 2010 & 0.832 & 0.720 & 0.477 & 0.787 & 0.776 \\
\hline Total sample & 0.851 & 0.742 & 0.503 & 0.814 & 0.794 \\
\hline \multicolumn{6}{|l|}{ Model 1 vs. Model 2} \\
\hline Kruskal-Wallis test & $47.34^{* *}$ & $22.83^{* *}$ & $23.08^{* *}$ & $4.79^{*}$ & $12.57^{* *}$ \\
\hline \multicolumn{6}{|c|}{$\begin{array}{l}\text { Notes: CF - cost function; IDF - input distance function; RF - } \\
\text { revenue function; SPF - standard profit functions; APF - alternative } \\
\text { profit function. } \\
\text { The Kruskal-Wallis test statistic is Chi-square distributed with } 1 \\
\text { degree of freedom. } \\
* \text { denotes significance at the } 5 \% \text { level and }{ }^{* *} \text { denotes significance } \\
\text { at the } 1 \% \text { level. }\end{array}$} \\
\hline
\end{tabular}


Table 5: Impact on the frontiers and inefficiency (model 1)

\begin{tabular}{|c|c|c|c|c|c|}
\hline Variable & $\mathrm{CF}$ & IDF & $\mathrm{RF}$ & SPF & $\mathrm{APF}$ \\
\hline \multicolumn{6}{|c|}{ Effect on the industry best practice frontier } \\
\hline$D L / T A$ & $0.356^{* * *}$ & $0.138^{*}$ & $-0.665^{* * *}$ & $-0.162^{*}$ & $-0.575^{* * *}$ \\
\hline DL Category $1 / D L$ & $-0.264^{* *}$ & 0.007 & $-1.483^{* * *}$ & $-0.258 * * *$ & $-0.192^{* *}$ \\
\hline DL Category $2 / D L$ & $0.139^{*}$ & -0.01 & $-1.431^{* * *}$ & $-0.174^{* *}$ & -0.029 \\
\hline DL Category $3 / D L$ & 0.06 & -0.015 & $-1.263^{* * *}$ & -0.062 & $0.283^{*}$ \\
\hline DL Category $4 / D L$ & 0.043 & $-0.104^{*}$ & $-1.667^{* * *}$ & -0.001 & -0.005 \\
\hline$B L / T A$ & $-1.343^{* * *}$ & $1.100^{* * *}$ & -0.273 & 0.141 & 0.342 \\
\hline$B L / S L$ & 0.004 & $0.007^{* *}$ & $-0.016^{* *}$ & -0.001 & -0.002 \\
\hline Foreign & $-2.048^{* * *}$ & $2.606^{* * *}$ & $-5.946^{* * *}$ & $-1.685^{* * *}$ & 0.131 \\
\hline State & $-1.862^{* * *}$ & $1.986^{* * *}$ & $-1.332^{* * *}$ & $-2.186^{* * *}$ & -0.311 \\
\hline Small & $-0.901^{* * *}$ & $0.940^{* * *}$ & 3.494 & 0.099 & 0.169 \\
\hline Large & -0.097 & -0.003 & 0.015 & $0.327^{* * *}$ & $0.299^{*}$ \\
\hline Negative Equity & -1.057 & 0.155 & 0.511 & $-0.517^{* * *}$ & $-0.244^{*}$ \\
\hline$Z$ - score & $-0.565^{* * *}$ & $0.526^{* * *}$ & $0.372^{* * *}$ & $-0.006^{* * *}$ & $-0.005^{* * *}$ \\
\hline \multicolumn{6}{|c|}{ Effect on banking inefficiency } \\
\hline$D L / T A$ & $-0.822^{* * *}$ & 0.166 & $-1.601^{* * *}$ & -3.581 & $-15.584^{* *}$ \\
\hline$D L$ Category $1 / D L$ & $0.344^{* *}$ & 0.058 & $-1.872^{* * *}$ & -7.689 & $-5.732^{* *}$ \\
\hline$D L$ Category $2 / D L$ & $-0.407 * * *$ & 0.13 & $-1.861^{* * *}$ & -4.664 & -2.047 \\
\hline$D L$ Category $3 / D L$ & 0.062 & 0.051 & $-1.843^{* * *}$ & -3.874 & 1.348 \\
\hline$D L$ Category $4 / D L$ & $-0.287^{*}$ & 0.026 & $-2.276^{* * *}$ & -1.109 & -0.457 \\
\hline$B L / T A$ & $1.426^{* * *}$ & $2.977^{* * *}$ & $1.241^{*}$ & 4.723 & $6.588^{*}$ \\
\hline Foreign & 1.235 & $0.632^{* * *}$ & 0.475 & -2.421 & -3.119 \\
\hline State & 0.049 & $-1.068^{* * *}$ & $0.362^{*}$ & -0.308 & 0.762 \\
\hline Small & $0.410^{* *}$ & -5.625 & $2.002^{* * *}$ & -34.517 & -31.464 \\
\hline Large & $0.443^{* * *}$ & $2.353^{* * *}$ & 4.419 & 0.037 & -0.127 \\
\hline Negative Equity & $0.280^{* *}$ & -0.174 & -0.272 & 3.09 & $5.903^{* *}$ \\
\hline Prudential_Req & -0.063 & 0.03 & -0.127 & -0.231 & 0.375 \\
\hline ForCur Limits & $0.189^{* *}$ & 0.031 & -0.275 & -1.476 & 0.659 \\
\hline
\end{tabular}

Notes: ${ }^{*}$ denotes significance at the $5 \%$ level; ${ }^{* *}$ denotes significance at the $1 \%$ level; $* * *$ denotes significance at the $0.1 \%$ level.

DL - doubtful loans; TA - total assets; BL - bad loans; SL - standard loans. Monthly unbalanced data consists of 46 time periods (from March 2007 to

Dec 2010) of 37 banks (1566 observations). 
Table 6: Impact on the frontiers and inefficiency (model 2)

\begin{tabular}{|c|c|c|c|c|c|}
\hline Variable & $\mathrm{CF}$ & IDF & $\mathrm{RF}$ & $\mathrm{SPF}$ & $\mathrm{APF}$ \\
\hline \multicolumn{6}{|c|}{ Effect on the industry best practice frontier } \\
\hline$R D L / T A$ & -0.027 & -0.051 & $-2.788 * * *$ & $-0.326^{* *}$ & $0.316^{*}$ \\
\hline$R D L$ Category $1 / R D L$ & 0.052 & -0.001 & -0.069 & $-0.100^{*}$ & $-0.142^{*}$ \\
\hline$R D L$ Category $2 / R D L$ & $0.091^{*}$ & 0.018 & $0.197^{*}$ & $-0.117^{*}$ & -0.11 \\
\hline RDL Category $3 / R D L$ & -0.06 & $0.159 * * *$ & $0.411^{* * *}$ & 0.069 & 0.091 \\
\hline RDL Category $4 / R D L$ & -0.005 & $-0.086^{*}$ & 0.072 & 0.096 & 0.059 \\
\hline$R B L / T A$ & -0.064 & 0.036 & $-2.871^{* * *}$ & $-0.334^{* *}$ & $0.405^{* *}$ \\
\hline Negative Equity & -0.142 & $-0.182^{* * *}$ & 1.024 & $-0.409 * * *$ & -0.116 \\
\hline$B L / S L$ & 0.001 & $0.005^{* *}$ & $-0.015^{*}$ & -0.003 & $-0.007^{*}$ \\
\hline Foreign & $-0.416^{* * *}$ & $0.821^{* * *}$ & $-0.823^{* * *}$ & $-1.567 * * *$ & 0.323 \\
\hline State & $-0.979 * * *$ & $1.318^{* * *}$ & & $-2.147^{* * *}$ & $-0.538^{*}$ \\
\hline Small & $-0.710^{* * *}$ & $1.256^{* * *}$ & 3.275 & 0.135 & $0.215^{*}$ \\
\hline Large & -0.02 & -0.012 & -0.142 & $0.251^{* *}$ & $0.253^{*}$ \\
\hline$Z$ - score & $-0.535^{* * *}$ & $0.455^{* * *}$ & $0.320 * * *$ & $-0.004^{* * *}$ & $-0.003^{*}$ \\
\hline \multicolumn{6}{|c|}{ Effect on banking inefficiency } \\
\hline$R D L / T A$ & $8.112^{*}$ & 0.197 & $-4.176 * * *$ & $-1.970^{*}$ & $-4.608^{*}$ \\
\hline RDL Category $1 / R D L$ & 0.022 & -0.057 & 0.077 & $-4.854^{* *}$ & $-11.851^{*}$ \\
\hline RDL Category $2 / R D L$ & $-1.195^{*}$ & 0.036 & 0.237 & $-6.128^{*}$ & -7.908 \\
\hline RDL Category $3 / R D L$ & $0.514^{*}$ & $0.305^{* * *}$ & 0.323 & $-2.204^{*}$ & -3.061 \\
\hline RDL Category $4 / R D L$ & -0.504 & -0.064 & 0.042 & -0.095 & -0.487 \\
\hline$R B L / T A$ & $8.258^{*}$ & $0.666^{* * *}$ & $-4.079 * * *$ & -0.414 & 0.477 \\
\hline Negative Equity & $1.272^{* * *}$ & -0.009 & $2.214^{* * *}$ & -0.694 & 1.025 \\
\hline Foreign & $0.503^{* *}$ & $-0.567^{* * *}$ & 0.2 & -0.799 & -0.156 \\
\hline State & $1.199^{* * *}$ & -6.014 & $2.051^{* * *}$ & -27.7 & -36.452 \\
\hline Small & $0.851^{* * *}$ & $1.340^{* * *}$ & 4.734 & 0.828 & 0.993 \\
\hline Large & -0.065 & -6.195 & $-0.646^{* *}$ & $1.202^{*}$ & 1.798 \\
\hline Prudential Req & -0.1 & 0.023 & -0.182 & 0.189 & 2.155 \\
\hline ForCur Limits & -0.062 & $0.214^{* *}$ & $-0.418^{*}$ & $-1.946^{*}$ & -2.089 \\
\hline
\end{tabular}

Notes: $*$ denotes significance at the $5 \%$ level; $* *$ denotes significance at the $1 \%$ level; $* * *$ denotes significance at the $0.1 \%$ level.

RDL - reserves on doubtful loans; TA - total assets; RBL - reserves on bad loans; BL - bad loans; SL - standard loans.

Monthly unbalanced data consists of 46 time periods (from March 2007 to Dec 2010) of 37 banks (1566 observations). 


\section{A Appendices}

\section{A.1 Four Further Functions and their Properties}

In addition to cost efficiency which was discussed in Section 3, four other efficiency measures are estimated in this paper. The four other efficiency measures are estimated by fitting an input distance function (IDF), revenue function (RF) and two specifications of the profit function, standard $(\mathrm{SPF})$ and alternative $(\mathrm{APF})$. These functions have the following forms:

$$
\begin{gathered}
-\ln x_{K i t}=\gamma+\lambda_{i}+T L\left(y_{i t}, x_{i t} / x_{K i t}\right)+\rho^{\prime} z_{i t}+v_{i t}-u_{i t} \\
-\ln \left(R_{i t} / p_{K i t}\right)=\gamma+\lambda_{i}+T L\left(x_{i t}, p_{i t} / p_{K i t}\right)+\rho^{\prime} z_{i t}+v_{i t}-u_{i t} \\
-\ln \left(\pi_{i t}+\theta / w_{K i t}\right)=\gamma+\lambda_{i}+T L\left(p_{i t}, w_{i t} / w_{K i t}\right)+\rho^{\prime} z_{i t}+v_{i t}-u_{i t} \\
-\ln \left(\pi_{i t}+\theta / w_{K i t}\right)=\gamma+\lambda_{i}+T L\left(y_{i t}, w_{i t} / w_{K i t}\right)+\rho^{\prime} z_{i t}+v_{i t}-u_{i t},
\end{gathered}
$$

where $x$ is a matrix of inputs in the banking technology; $y$ is a matrix of outputs; $w$ is a matrix of input prices; $p$ is a matrix of output prices; $R$ is a vector of banks' revenues; $\pi$ is a vector of banks' profits; $\theta$ is a constant added to every bank's profit so that the natural log is a positive number.

As was the case for the cost function the error components are $v$ and $u$. Unlike for the cost function, however, the inefficiency term $u$ is subtracted for the other functions. This is because cost inefficiency measures the distance to the minimum attainable cost whereas standard profit, alternative profit and revenue inefficiency measure the distance to the maximum achievable level. Technical efficiency from a fitted input distance function measures how close a bank's usage of resources is to the minimum attainable level of inputs. Given the input distance function is an input requirement function multiplied by -1 , inefficiency is subtracted rather than added.

Information on the quantities of inputs and outputs is needed to represent the production technology using the input distance function, $D_{I}(y, x)$. $D_{I}(y, x)$ is defined according to the input set and satisfies the following properties:

(i) non-decreasing in inputs $x, \partial \ln D_{I} / \partial \ln x_{k} \equiv e x_{k} \geq 0, k=1, \ldots, K$;

(ii) non-increasing in outputs $y, \partial \ln D_{I} / \partial \ln y_{m} \equiv e y_{m} \leq 0, m=1, \ldots, M$;

(iii) homogeneity of degree one in inputs $x, D_{I}\left(y, x / x_{K}\right)=D_{I}(y, x) / x_{K}$;

(iv) concave and continuous function in inputs $x$.

Estimating the revenue function, $r(x, p)$, is based on the assumption that producers attempt to maximize their revenue. Information on inputs and output prices is required to estimate the revenue function. The revenue function satisfies the following properties:

(i) non-decreasing in output prices $p, \partial \ln r(x, p) / \partial \ln p_{m} \equiv e p_{m} \geq 0, m=1, \ldots, M$;

(ii) non-decreasing in inputs $x, \partial \ln r(x, p) / \partial \ln x_{k} \equiv e x_{k} \geq 0, k=1, \ldots, K$;

(iii) homogeneity of degree one in output prices $p, r\left(y, p / p_{M}\right)=r(y, p) / p_{M}$

(iv) convex and continuous function in output prices $p$.

To fit the standard profit function, $\pi(p, w)$, information on input and output prices is required. The standard profit function has the following properties:

(i) non-decreasing in output prices $p, \partial \ln \pi(w, p) / \partial \ln p_{m} \equiv e p_{m} \geq 0, m=1, \ldots, M$;

(ii) non-increasing in input prices $w, \partial \ln \pi(w, p) / \partial \ln w_{k} \equiv e w_{k} \leq 0, k=1, \ldots, K$;

(iii) homogeneity of degree one in output prices $p$ and input prices $w, \pi\left(w, p / p_{M}\right)=$ $\pi(w, p) / p_{M}$ and $\pi\left(w / w_{K}, p\right)=\pi(w, p) / w_{K}$;

(iv) convex and continuous function in output prices $p$ and input prices $w$. 
The right-hand side of the alternative profit function is the same as the right-hand side of the cost function. The standard and alternative profit functions have the same dependent variable. The alternative profit function, $\pi^{*}(y, w)$, therefore holds output levels constant, as is the case in the cost function, and allows output prices to vary and influence profit. The properties of the alternative profit function are:

(i) non-decreasing in outputs $y, \partial \ln \pi^{*}(y, w) / \partial \ln y_{m} \equiv e y_{m} \geq 0, m=1, \ldots, M$;

(ii) non-increasing in input prices $w, \partial \ln \pi^{*}(y, w) / \partial \ln w_{k} \equiv e w_{k} \leq 0, k=1, \ldots, K$;

(iii) homogeneity of degree one in input prices $w, \pi^{*}\left(y, w / w_{K}\right)=\pi^{*}(y, w) / w_{K}$;

(iv) convex and continuous function in input prices $w$.

All the functions fitted here contain the translog approximation of the relevant function. The general form of the translog approximation of each function for panel data at time $t$ is as follows:

$$
T L(a, b)=\alpha^{\prime} l a+\beta^{\prime} l b+\frac{1}{2} \mathbf{A} l a^{\prime} l a+\frac{1}{2} \mathbf{B} l b^{\prime} l b+l a \boldsymbol{\Gamma} l b+\eta_{1} t+\frac{1}{2} \eta_{2} t^{2}+\psi^{\prime} l a t+\phi^{\prime} l b t
$$

where $l a=\ln (a) ; l b=\ln (b) ; \eta_{1}$ and $\eta_{2}$ are parameters to be estimated; $\alpha^{\prime}, \beta^{\prime}, \psi^{\prime}$ and $\phi^{\prime}$ are vectors of parameters to be estimated; $\mathbf{A}, \mathbf{B}$ and $\boldsymbol{\Gamma}$ are matrices of parameters to be estimated. The signs of the elements of $\alpha^{\prime}$ and $\beta^{\prime}$ indicate whether the monotonicity conditions of $T L(a, b)$ are satisfied. 


\section{A.2 The Fitted Functions}

Estimation results for model 1 (volume of loans categorization)

\begin{tabular}{|c|c|c|c|c|c|c|c|c|c|}
\hline \multicolumn{2}{|c|}{$\mathrm{CF}$} & \multicolumn{2}{|c|}{ IDF } & \multicolumn{2}{|c|}{$\mathbf{R F}$} & \multicolumn{2}{|c|}{ SPF } & \multicolumn{2}{|c|}{ APF } \\
\hline$T C / w_{1}$ & $L H S$ & $-l x_{1}$ & $L H S$ & $T R / p_{1}$ & $L H S$ & $\pi^{*} / w_{1}$ & $L H S$ & $\pi^{*} / w_{1}$ & $L H S$ \\
\hline$y_{1}$ & $0.385 * * *$ & $y_{1}$ & $-0.274 * * *$ & $x_{1}$ & 0.033 & $p 1$ & $-0.112^{* * *}$ & $y 1$ & $0.344 * * *$ \\
\hline$y_{2}$ & $0.032^{* * *}$ & $y_{2}$ & $-0.013^{* *}$ & $x_{2}$ & $0.346^{* * *}$ & $p 2$ & -0.006 & $y 2$ & 0.002 \\
\hline$y_{3}$ & $0.044^{* * *}$ & $y_{3}$ & $-0.015^{*}$ & $x_{3}$ & $0.087^{* *}$ & $p 3$ & $0.024^{* * *}$ & $y 3$ & 0.014 \\
\hline$w_{2} / w_{1}$ & $0.198^{* * *}$ & $x_{2} / x_{1}$ & $0.487 * * *$ & $p_{2} / p_{1}$ & $0.058^{* * *}$ & $w_{2} / w_{1}$ & $0.092^{* * *}$ & $w_{2} / w_{1}$ & $-0.051^{* *}$ \\
\hline$w_{3} / w_{1}$ & $0.602^{* * *}$ & $x_{3} / x_{1}$ & $0.138^{* * *}$ & $p_{3} / p_{1}$ & $0.307^{* * *}$ & $w_{3} / w_{1}$ & $0.502^{* * *}$ & $w_{3} / w_{1}$ & $0.603^{* * *}$ \\
\hline$\left(y_{1}\right)^{2}$ & $0.048^{* * *}$ & $\left(y_{1}\right)^{2}$ & $-0.034^{* * *}$ & $\left(x_{1}\right)^{2}$ & $-0.060 * * *$ & $\left(p_{1}\right)^{2}$ & 0.003 & $\operatorname{ly} 11$ & $0.077^{*} * *$ \\
\hline$\left(y_{2}\right)^{2}$ & $0.004^{* * *}$ & $\left(y_{2}\right)^{2}$ & $-0.002^{*}$ & $\left(x_{2}\right)^{2}$ & -0.008 & $\left(p_{2}\right)^{2}$ & 0.005 & $\operatorname{ly} 22$ & 0.001 \\
\hline$\left(y_{3}\right)^{2}$ & -0.001 & $\left(y_{3}\right)^{2}$ & $-0.002^{*}$ & $\left(x_{3}\right)^{2}$ & -0.02 & $\left(p_{3}\right)^{2}$ & $0.010^{* * *}$ & $\operatorname{ly} 33$ & $0.008^{* * *}$ \\
\hline$y_{1} y_{2}$ & -0.002 & $y_{1} y_{2}$ & 0.003 & $x_{1} x_{2}$ & $0.117 * * *$ & $p_{1} p_{2}$ & $-0.049 * * *$ & $\operatorname{ly} 12$ & $-0.014^{* *}$ \\
\hline$y_{1} y_{3}$ & 0.003 & $y_{1} y_{3}$ & -0.004 & $x_{1} x_{3}$ & -0.007 & $p_{1} p_{3}$ & $0.034^{* * *}$ & $\operatorname{ly} 13$ & $-0.024 * * *$ \\
\hline$y_{2} y_{3}$ & $-0.004 * * *$ & $y_{2} y_{3}$ & $0.002^{*}$ & $x_{2} x_{3}$ & 0.017 & $p_{2} p_{3}$ & $-0.007 * *$ & $\operatorname{ly} 23$ & $0.006^{* *}$ \\
\hline$\left(w_{2} / w_{1}\right)^{2}$ & $0.004^{* * *}$ & $\left(x_{2} / x_{1}\right)^{2}$ & $0.055^{* * *}$ & $\left(p_{2} / p_{1}\right)^{2}$ & 0.000 & $\left(w_{2} / w_{1}\right)^{2}$ & $0.021 * * *$ & $\left(w_{2} / w_{1}\right)^{2}$ & $0.037^{* * *}$ \\
\hline$\left(w_{3} / w_{1}\right)^{2}$ & $0.055^{* * *}$ & $\left(x_{3} / x_{1}\right)^{2}$ & 0.006 & $\left(p_{3} / p_{1}\right)^{2}$ & $0.028^{* * *}$ & $\left(w_{3} / w_{1}\right)^{2}$ & $0.084^{* * *}$ & $\left(w_{3} / w_{1}\right)^{2}$ & $0.147^{* * *}$ \\
\hline$\left(w_{2} / w_{1}\right) *$ & & $\left(x_{2} / x_{1}\right) *$ & & $\left(p_{2} / p_{1}\right) *$ & & $\left(w_{2} / w_{1}\right) *$ & & $\left(w_{2} / w_{1}\right) *$ & \\
\hline$\left(w_{3} / w_{1}\right)$ & $-0.043 * * *$ & $\left(x_{3} / x_{1}\right)$ & $-0.014^{*}$ & $\left(p_{3} / p_{1}\right)$ & $0.025 * * *$ & $\left(w_{3} / w_{1}\right)$ & $-0.058 * * *$ & $\left(w_{3} / w_{1}\right)$ & $-0.113 * * *$ \\
\hline$y_{1}\left(w_{2} / w_{1}\right)$ & $0.034^{* * *}$ & $y_{1}\left(x_{2} / x_{1}\right)$ & 0.002 & $x 1\left(p_{2} / p_{1}\right)$ & 0.016 & $p_{1}\left(w_{2} / w_{1}\right)$ & $0.033^{* * *}$ & $y_{1}\left(w_{2} / w_{1}\right)$ & $-0.020 * *$ \\
\hline$y_{1}\left(w_{3} / w_{1}\right)$ & $-0.070^{* * *}$ & $y_{1}\left(x_{3} / x_{1}\right)$ & 0.01 & $x 1\left(p_{3} / p_{1}\right)$ & $-0.026^{*}$ & $p_{1}\left(w_{3} / w_{1}\right)$ & $-0.058^{* * *}$ & $y_{1}\left(w_{3} / w_{1}\right)$ & -0.001 \\
\hline$y_{2}\left(w_{2} / w_{1}\right)$ & $-0.004^{* * *}$ & $y_{2}\left(x_{2} / x_{1}\right)$ & $0.003^{*}$ & $x 2\left(p_{2} / p_{1}\right)$ & 0.011 & $p_{2}\left(w_{2} / w_{1}\right)$ & $-0.015^{* * *}$ & $y_{2}\left(w_{2} / w_{1}\right)$ & 0.002 \\
\hline$y_{2}\left(w_{3} / w_{1}\right)$ & $0.023 * * *$ & $y_{2}\left(x_{3} / x_{1}\right)$ & 0 & $x 2\left(p_{3} / p_{1}\right)$ & $0.042 * * *$ & $p_{2}\left(w_{3} / w_{1}\right)$ & $0.037 * * *$ & $y_{2}\left(w_{3} / w_{1}\right)$ & 0.006 \\
\hline$y_{3}\left(w_{2} / w_{1}\right)$ & $0.009^{* * *}$ & $y_{3}\left(x_{2} / x_{1}\right)$ & 0.004 & $x 3\left(p_{2} / p_{1}\right)$ & $-0.020^{*}$ & $p_{3}\left(w_{2} / w_{1}\right)$ & 0.003 & $y_{3}\left(w_{2} / w_{1}\right)$ & $-0.021 * * *$ \\
\hline$y_{3}\left(w_{3} / w_{1}\right)$ & $-0.017 * * *$ & $y_{3}\left(x_{3} / x_{1}\right)$ & $-0.014^{* *}$ & $x 3\left(p_{3} / p_{1}\right)$ & 0.013 & $p_{3}\left(w_{3} / w_{1}\right)$ & $-0.061 * * *$ & $y_{3}\left(w_{3} / w_{1}\right)$ & $0.032^{* *}$ \\
\hline$t$ & $0.009^{* * *}$ & $t$ & $-0.009^{* * *}$ & $t$ & $0.006^{* * *}$ & $t$ & -0.001 & $t$ & 0.000 \\
\hline$t^{2}$ & $-0.000 * * *$ & $t^{2}$ & 0.000 & $t^{2}$ & $0.000^{* * *}$ & $t^{2}$ & 0.000 & $t^{2}$ & 0.000 \\
\hline$y_{1} t$ & $0.002^{* * *}$ & $y_{1} t$ & $0.001^{* *}$ & $x_{1} t$ & $-0.003^{* *}$ & $p_{1} t$ & $-0.003^{* *}$ & $y_{1} t$ & -0.002 \\
\hline$y_{2} t$ & 0.000 & $y_{2} t$ & $-0.000^{* *}$ & $x_{2} t$ & $-0.002^{*}$ & $p_{2} t$ & $-0.001^{*}$ & $y_{2} t$ & 0.000 \\
\hline & $-0.001 * * *$ & $y_{3} t$ & 0.000 & $x_{3} t$ & 0.002 & $p_{3} t$ & 0.001 & $y_{3} t$ & $0.003^{* * *}$ \\
\hline$\left(w_{2} / w_{1}\right) t$ & $-0.003^{* * *}$ & $\left(x_{2} / x_{1}\right) t$ & $-0.002 * * *$ & $\left(p_{2} / p_{1}\right) t$ & $0.002 * * *$ & $\left(w_{2} / w_{1}\right) t$ & $-0.003^{* * *}$ & $\left(w_{2} / w_{1}\right) t$ & $-0.006 * * *$ \\
\hline$\left(w_{3} / w_{1}\right) t$ & 0.000 & $\left(x_{3} / x_{1}\right) t$ & $-0.001^{*}$ & $\left(p_{3} / p_{1}\right) t$ & $0.003^{* * *}$ & $\left(w_{3} / w_{1}\right) t$ & 0.000 & $\left(w_{3} / w_{1}\right) t$ & $0.004^{* * *}$ \\
\hline $\begin{array}{l}\text { Log- } \\
\text { Like- }\end{array}$ & & & & & & & & & \\
\hline lihood & 288.79 & & 466.92 & & -967.21 & & -327.06 & & -666.74 \\
\hline
\end{tabular}

Notes: CF - cost function; IDF - input distance function; RF - revenue function; SPF - standard profit function; APF - alternative profit function. All regressions include individual fixed effects for banks (not reported in the table).

$*$ denotes significance at the $5 \%$ level; $* *$ denotes significance at the $1 \%$ level; $* * *$ denotes significance at the $0.1 \%$ level. 
Estimation results for model 2 (loan loss provisions categorization)

\begin{tabular}{|c|c|c|c|c|c|c|c|c|c|}
\hline \multicolumn{2}{|c|}{ CF } & \multicolumn{2}{|c|}{ IDF } & \multicolumn{2}{|c|}{ RF } & \multicolumn{2}{|c|}{ SPF } & \multicolumn{2}{|c|}{$\mathbf{A P F}$} \\
\hline$T C / w_{1}$ & $L H S$ & $-l x_{1}$ & $L H S$ & $T R / p_{1}$ & $L H S$ & $\pi^{*} / w_{1}$ & $L H S$ & $\pi^{*} / w_{1}$ & $L H S$ \\
\hline$y_{1}$ & $0.502^{* * *}$ & $y_{1}$ & $-0.288^{* * *}$ & $x_{1}$ & -0.027 & $p 1$ & $-0.146^{* * *}$ & $y 1$ & $0.289 * * *$ \\
\hline$y_{2}$ & $0.028 * * *$ & $y_{2}$ & $-0.023^{* * *}$ & $x_{2}$ & $0.387 * * *$ & $p 2$ & 0.000 & $y 2$ & 0.012 \\
\hline$y_{3}$ & $0.037 * * *$ & $y_{3}$ & $-0.021 * * *$ & $x_{3}$ & $0.129 * * *$ & $p 3$ & $0.025 * * *$ & $y 3$ & 0.014 \\
\hline$w_{2} / w_{1}$ & $0.225^{* * *}$ & $x_{2} / x_{1}$ & $0.465^{* * *}$ & $p_{2} / p_{1}$ & $0.034 * * *$ & $w_{2} / w_{1}$ & $0.115^{* * *}$ & $w_{2} / w_{1}$ & $-0.064 * * *$ \\
\hline$w_{3} / w_{1}$ & $0.566^{* * *}$ & $x_{3} / x_{1}$ & $0.127 * * *$ & $p_{3} / p_{1}$ & $0.292^{* * *}$ & $w_{3} / w_{1}$ & $0.490^{* * *}$ & $w_{3} / w_{1}$ & $0.614^{* * *}$ \\
\hline$\left(y_{1}\right)^{2}$ & $0.068 * * *$ & $\left(y_{1}\right)^{2}$ & $-0.054 * * *$ & $\left(x_{1}\right)^{2}$ & $-0.074 * * *$ & $\left(p_{1}\right)^{2}$ & $-0.013^{*}$ & $\operatorname{ly} 11$ & $0.075 * * *$ \\
\hline$\left(y_{2}\right)^{2}$ & $0.003^{* * *}$ & $\left(y_{2}\right)^{2}$ & $-0.004^{* * *}$ & $\left(x_{2}\right)^{2}$ & $-0.018^{*}$ & $\left(p_{2}\right)^{2}$ & $0.007 * *$ & $\operatorname{ly} 22$ & 0.001 \\
\hline$\left(y_{3}\right)^{2}$ & -0.001 & $\left(y_{3}\right)^{2}$ & $-0.002 *$ & $\left(x_{3}\right)^{2}$ & -0.022 & $\left(p_{3}\right)^{2}$ & $0.008^{* * *}$ & $\operatorname{ly} 33$ & $0.007 * * *$ \\
\hline$y_{1} y_{2}$ & 0.001 & $y_{1} y_{2}$ & $0.007^{* *}$ & $x_{1} x_{2}$ & $0.168^{* * *}$ & $p_{1} p_{2}$ & $-0.053 * * *$ & $\operatorname{ly} 12$ & -0.008 \\
\hline$y_{1} y_{3}$ & $-0.010^{* *}$ & $y_{1} y_{3}$ & 0.000 & $x_{1} x_{3}$ & -0.02 & $p_{1} p_{3}$ & $0.038^{* * *}$ & $\operatorname{ly} 13$ & $-0.024^{* * *}$ \\
\hline$y_{2} y_{3}$ & -0.001 & $y_{2} y_{3}$ & 0.000 & $x_{2} x_{3}$ & 0.018 & $p_{2} p_{3}$ & -0.004 & $\operatorname{ly} 23$ & $0.006^{* *}$ \\
\hline$\left(w_{2} / w_{1}\right)^{2}$ & $0.007^{* * *}$ & $\left(x_{2} / x_{1}\right)^{2}$ & $0.041^{* * *}$ & $\left(p_{2} / p_{1}\right)^{2}$ & 0.002 & $\left(w_{2} / w_{1}\right)^{2}$ & $0.021^{* * *} *$ & $\left(w_{2} / w_{1}\right)^{2}$ & $0.041^{* * *}$ \\
\hline$\left(w_{3} / w_{1}\right)^{2}$ & $0.062 * * *$ & $\left(x_{3} / x_{1}\right)^{2}$ & $0.014 * * *$ & $\left(p_{3} / p_{1}\right)^{2}$ & $0.031 * * *$ & $\left(w_{3} / w_{1}\right)^{2}$ & $0.087^{* * *}$ & $\left(w_{3} / w_{1}\right)^{2}$ & $0.172^{* * *}$ \\
\hline$\left(w_{2} / w_{1}\right) *$ & & $\left(x_{2} / x_{1}\right) *$ & & $\left(p_{2} / p_{1}\right) *$ & & $\left(w_{2} / w_{1}\right) *$ & & $\left(w_{2} / w_{1}\right) *$ & \\
\hline$\left(w_{3} / w_{1}\right)$ & $-0.037 * * *$ & $\left(x_{3} / x_{1}\right)$ & $-0.024 * * *$ & $\left(p_{3} / p_{1}\right)$ & $0.016^{* * *}$ & $\left(w_{3} / w_{1}\right)$ & $-0.060 * * *$ & $\left(w_{3} / w_{1}\right)$ & $-0.138 * * *$ \\
\hline$y_{1}\left(w_{2} / w_{1}\right)$ & $0.056^{* * *}$ & $y_{1}\left(x_{2} / x_{1}\right)$ & $-0.026^{* *}$ & $x 1\left(p_{2} / p_{1}\right)$ & $0.020^{*}$ & $p_{1}\left(w_{2} / w_{1}\right)$ & $0.035^{* * *}$ & $y_{1}\left(w_{2} / w_{1}\right)$ & $-0.039 * * *$ \\
\hline$y_{1}\left(w_{3} / w_{1}\right)$ & $-0.047 * * *$ & $y_{1}\left(x_{3} / x_{1}\right)$ & 0.014 & $x 1\left(p_{3} / p_{1}\right)$ & -0.004 & $p_{1}\left(w_{3} / w_{1}\right)$ & $-0.058 * * *$ & $y_{1}\left(w_{3} / w_{1}\right)$ & 0.029 \\
\hline$y_{2}\left(w_{2} / w_{1}\right)$ & $-0.004 * * *$ & $y_{2}\left(x_{2} / x_{1}\right)$ & $0.008^{* * *}$ & $x 2\left(p_{2} / p_{1}\right)$ & 0.011 & $p_{2}\left(w_{2} / w_{1}\right)$ & $-0.021 * * *$ & $y_{2}\left(w_{2} / w_{1}\right)$ & 0.003 \\
\hline$y_{2}\left(w_{3} / w_{1}\right)$ & $0.021^{* * *}$ & $y_{2}\left(x_{3} / x_{1}\right)$ & $0.007^{* *}$ & $x 2\left(p_{3} / p_{1}\right)$ & $0.047 * * *$ & $p_{2}\left(w_{3} / w_{1}\right)$ & $0.038^{* * *}$ & $y_{2}\left(w_{3} / w_{1}\right)$ & $0.011^{*}$ \\
\hline$y_{3}\left(w_{2} / w_{1}\right)$ & $0.009^{* *}$ & $y_{3}\left(x_{2} / x_{1}\right)$ & $0.010^{*}$ & $x 3\left(p_{2} / p_{1}\right)$ & $-0.020^{*}$ & $p_{3}\left(w_{2} / w_{1}\right)$ & 0.003 & $y_{3}\left(w_{2} / w_{1}\right)$ & $-0.021 * * *$ \\
\hline$y_{3}\left(w_{3} / w_{1}\right)$ & $-0.030^{* * *}$ & $y_{3}\left(x_{3} / x_{1}\right)$ & -0.004 & $x 3\left(p_{3} / p_{1}\right)$ & -0.018 & $p_{3}\left(w_{3} / w_{1}\right)$ & $-0.059 * * *$ & $y_{3}\left(w_{3} / w_{1}\right)$ & $0.024^{*}$ \\
\hline$t$ & $0.009 * * *$ & $t$ & $-0.006 * * *$ & $t$ & $0.003^{*}$ & $t$ & 0.000 & $t$ & 0.000 \\
\hline$t^{2}$ & $-0.000^{* * *}$ & $t^{2}$ & 0.000 & $t^{2}$ & $0.000 * * *$ & $t^{2}$ & 0.000 & $t^{2}$ & 0.000 \\
\hline$y_{1} t$ & $0.003^{* * *}$ & $y_{1} t$ & 0.000 & $x_{1} t$ & 0.000 & $p_{1} t$ & $-0.003^{* *}$ & $y_{1} t$ & -0.001 \\
\hline$y_{2} t$ & 0.000 & $y_{2} t$ & 0.000 & $x_{2} t$ & $-0.003 * * *$ & $p_{2} t$ & $-0.001 * *$ & $y_{2} t$ & 0.000 \\
\hline & $-0.001^{*}$ & $y 3 t$ & 0.000 & $x_{3} t$ & 0.001 & $p_{3} t$ & 0.001 & $y 3 t$ & $0.003^{* * *}$ \\
\hline$\left(w_{2} / w_{1}\right) t$ & $-0.003^{* * *}$ & $\left(x_{2} / x_{1}\right) t$ & $-0.003^{* * *}$ & $\left(p_{2} / p_{1}\right) t$ & $0.001^{*}$ & $\left(w_{2} / w_{1}\right) t$ & $-0.003^{* * *}$ & $\left(w_{2} / w_{1}\right) t$ & $-0.005^{* * *}$ \\
\hline$\left(w_{3} / w_{1}\right) t$ & $0.001^{*}$ & $\left(x_{3} / x_{1}\right) t$ & $-0.001^{*}$ & $\left(p_{3} / p_{1}\right) t$ & $0.002^{* *}$ & $\left(w_{3} / w_{1}\right) t$ & 0.000 & $\left(w_{3} / w_{1}\right) t$ & $0.003^{* *}$ \\
\hline $\begin{array}{l}\text { Log- } \\
\text { Like- }\end{array}$ & & & & & & & & & \\
\hline lihood & 333.22 & & 520.47 & & -778.63 & & -267.06 & & -614.56 \\
\hline
\end{tabular}

Notes: CF - cost function; IDF - input distance function; RF - revenue function; SPF - standard profit function; APF - alternative profit function. All regressions include individual fixed effects for banks (not reported in the table).

$*$ denotes significance at the $5 \%$ level; $* *$ denotes significance at the $1 \%$ level; *** denotes significance at the $0.1 \%$ level. 